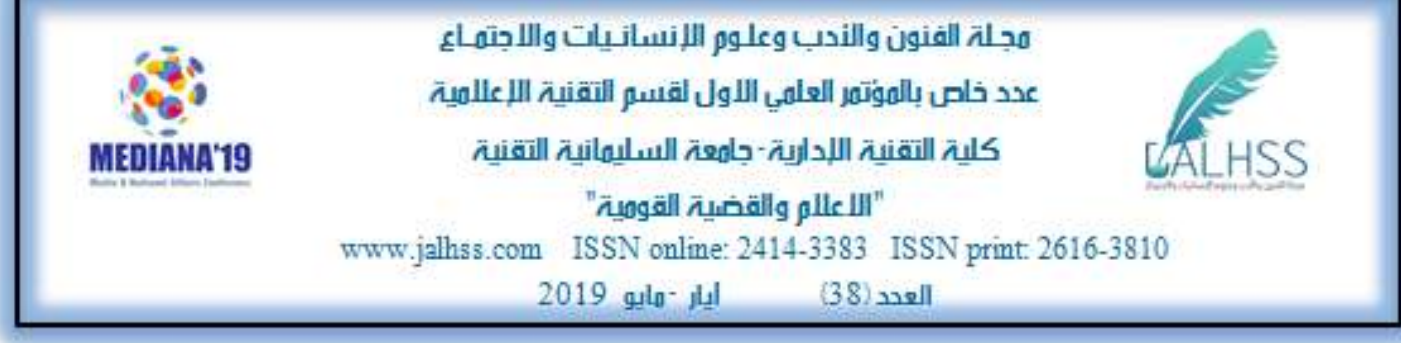

\title{
دور الإعلام الكردي في تشكيل الرأي العام تجاه حق تقرير شعب

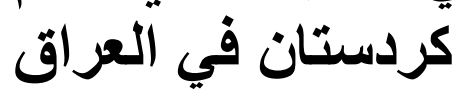

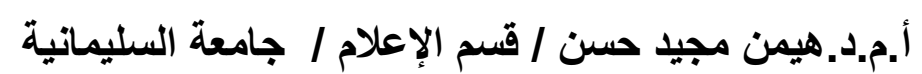

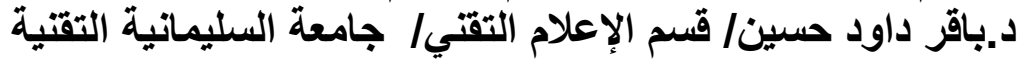

م.كامل عمر / قَم الإعلام / جامعة السليمانية

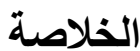

يتناول هذا البحث موضوع الإعلام الكردي فيما يتعلق بحق تقرير المصير ، والذي بعده الأكراد لقضيته

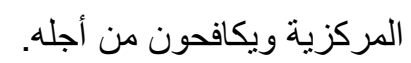

تكمن أهمية هذا البحث في أهمية مكوناته الأساسية التي تمثلها وسائل الإعلام الكردية و الحق في تقرير المصير

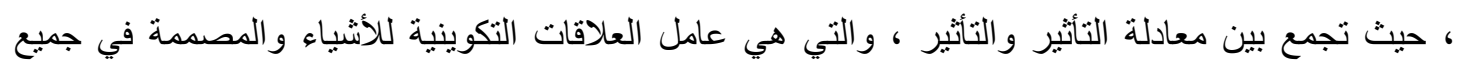

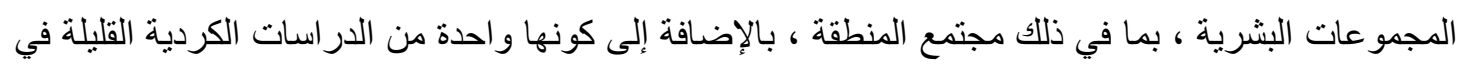
هذا المجال ، لإلقاء نظرة إيجابية على مشغلي الثشروط المرجعية.

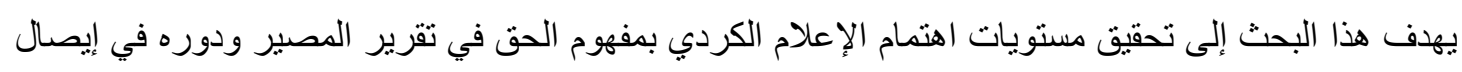

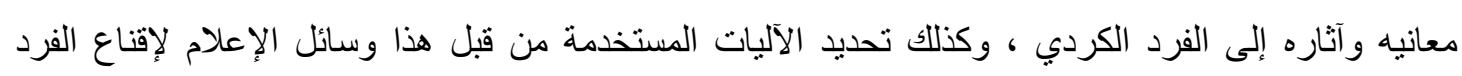
المذكورة هذا الحق وتفعيل ميوله تجاهه.

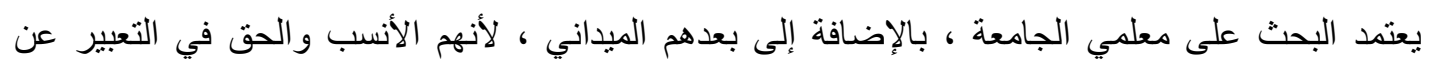

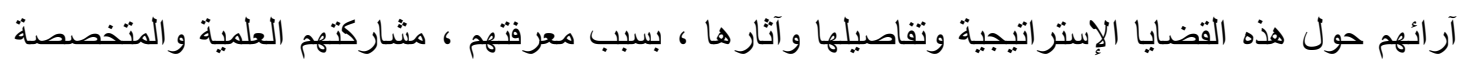

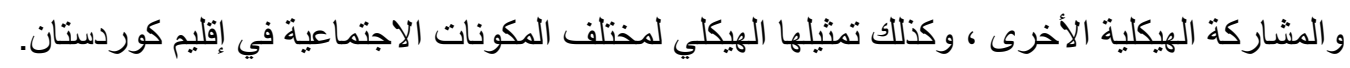




\title{
The role of the Kurdish Media in Shaping Public Opinion towards theRight to Decide the People of Kurdistan in Iraq
}

\begin{abstract}
This research deals with the subject of the Kurdish media in relation to the right of self-determination, which the Kurds prepare for its central cause and struggle for it.

The importance of this research comes from the importance of its basic components represented by the Kurdish media and the right to self-determination, where they combine the equation of influence and influence, which is the operator of the formative relations of things and designed in all human groups, including the community of the region, in addition to being one of the few Kurdish studies in this field, To cast its positive on the operators of the terms of reference.

The aim of this research is to realize the levels of interest of the Kurdish media in the concept of the right to self-determination and its role in conveying its meanings and implications to the Kurdish individual, as well as to identify the mechanisms used by this media to convince the individual mentioned this right and activate his tendencies toward him.

The research depends on the university teachers, in addition to their field dimension, because they are the most appropriate and the right to express opinions about such strategic issues and their details and implications, because of their knowledge, scientific, specialized and other structural participants, as well as their structural representation of various social components in the Kurdistan Region.
\end{abstract}


مجلة الفنون والندب وعلوم اللإنسانيات واللاجتهاع

عدد خام بالموتتمر العلمي الاول لقسم التقنية اللاعلامية

كلية التقنية اللادارية-جامعت السليمانية التقنية

"اللاعلام والقضياة القومية"

www.jalhss.com ISSN online: 2414-3383 ISSN print: 2616-3810

العدد (38) ايار -هايو 2019

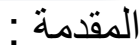

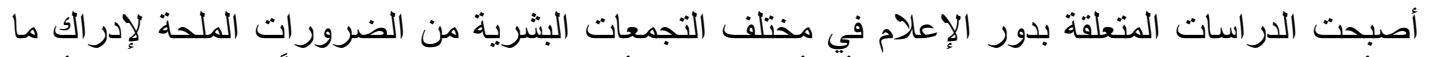

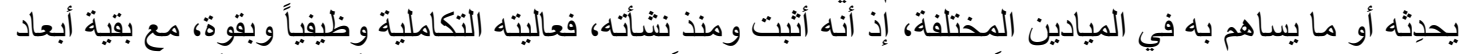

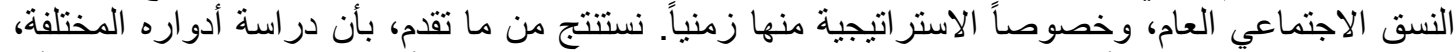

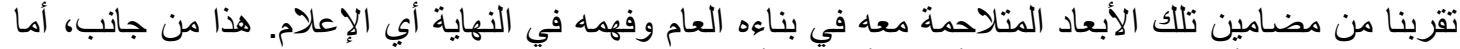

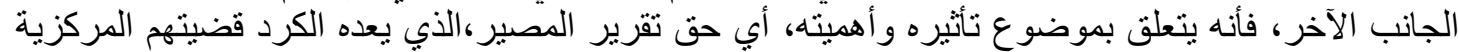

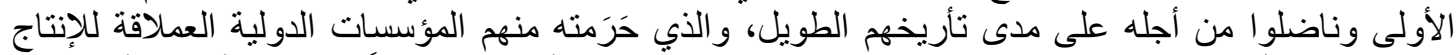

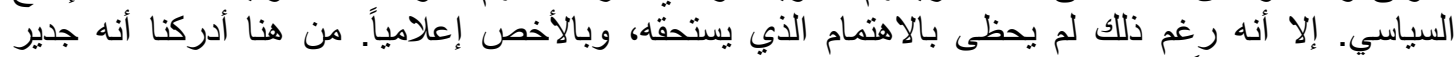

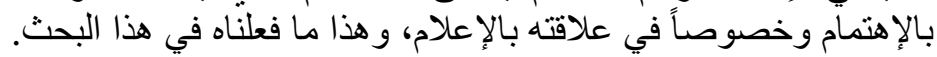

\section{الفصل الأول: الإطار المنهجي للبحث}

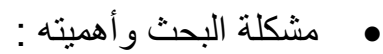

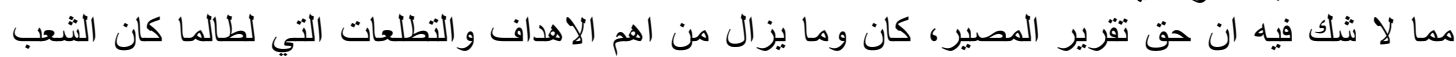

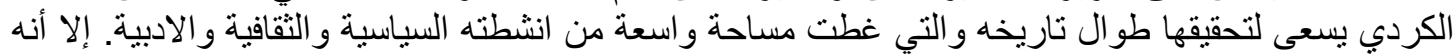

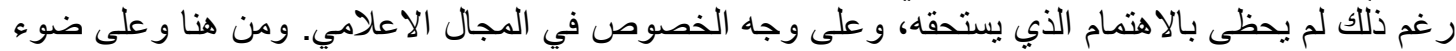

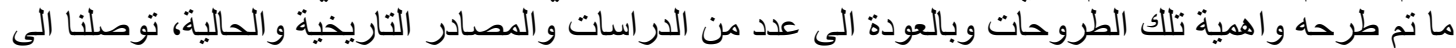

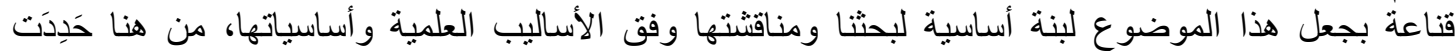

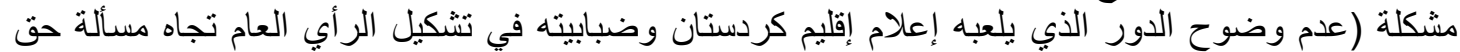
تقرير المصير لشعب كردستان)، مشكلة بنيوية لهذا التها البحث.

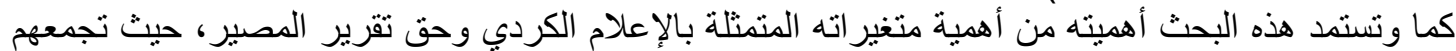

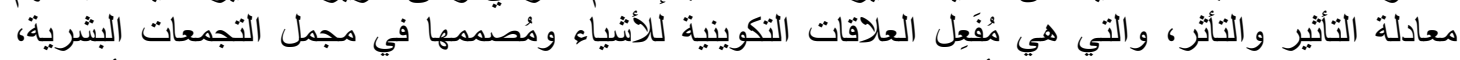

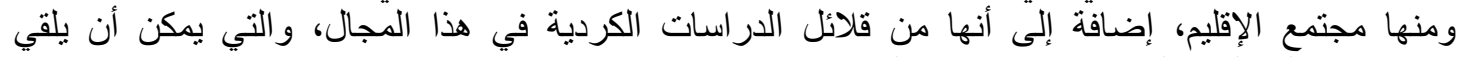

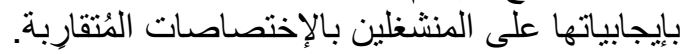

$$
\text { • • بهدف هذا البحث البحث : تحقيق مائتي من الإهداف : }
$$

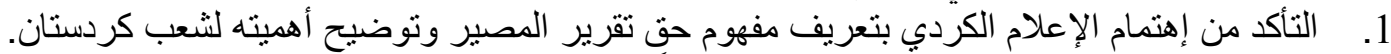

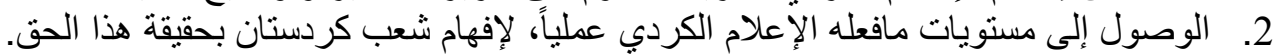

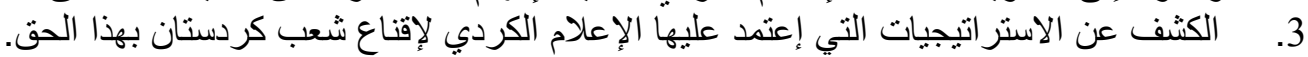

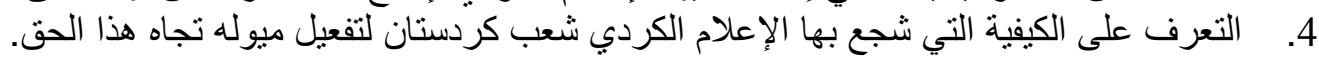

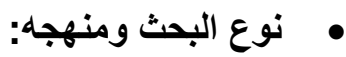

ينتمي هذا البحث إلى البحوث الوصفية، حيث يتناول من خلاله مايتعلق بمتغير اته الأساسية وتوضيحها، بهدف

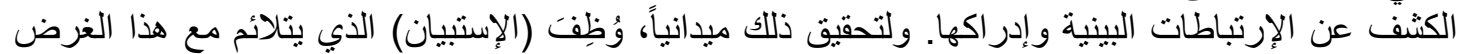

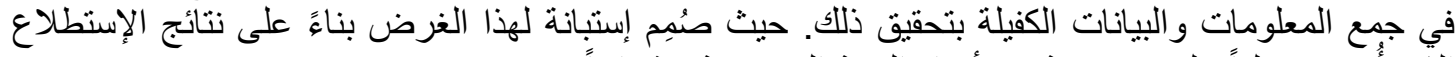

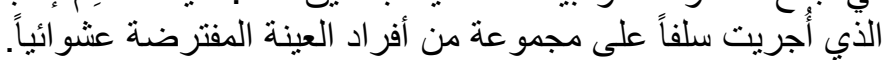




\section{مجلة الفنون والندب وعلوم اللإنسانيات واللاجتهـاع \\ عدد خام بالموتمر العلميا اللاول لقسم التقنية اللعالمية كلية التقنية اللإدارية-جامعت السليمانية التقنية}

"اللاعلام والقفياة القومية"

www.jalhss.com ISSN online: 2414-3383 ISSN print: 2616-3810

العدد (38) ايار -هايو 2019

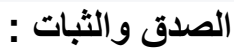

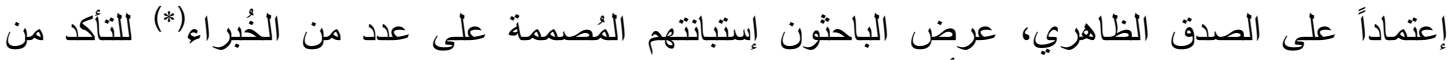

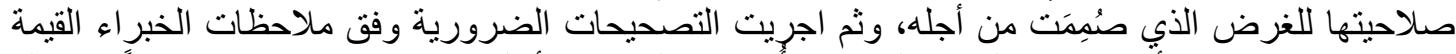

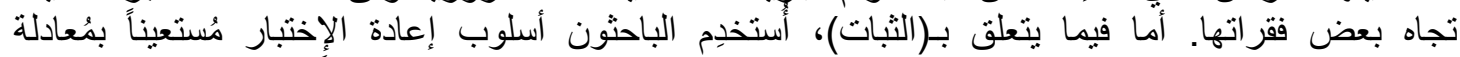
(هولستي) لإدر اك درجة ثبات الأسنبيان، إذ بلغت (83.31\%)، وهي نسبة مقبولة علمياً.

تتجسد المجال المكاني لهذا البحث في مركز محافظة السليمانية ومجاله الزماني مفتوح، و المجال البشري تتجسد في التدريسيين الجامعين العاملين في جامعتي السيني السليمانية والتتمية البشرية في في محافظة السليمانية

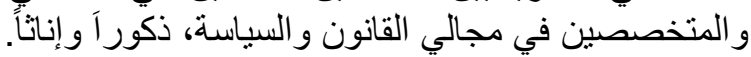

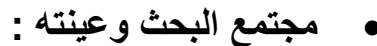

يتكون مجتمع هذا البحث من التدريسيين الجامعيين المتخصصين في مجالي القانون والسياسة. أما العينة

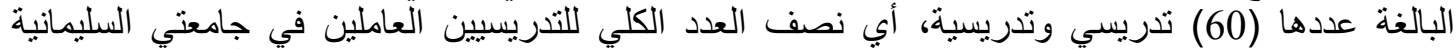

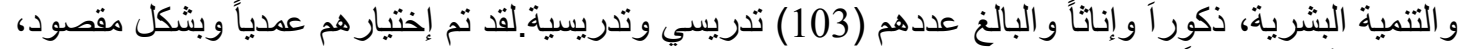

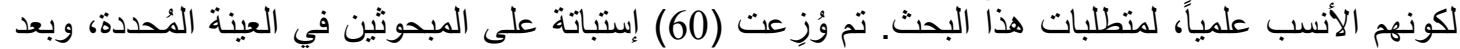

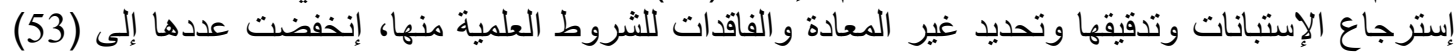

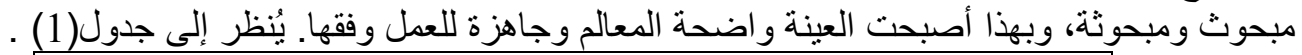

\begin{tabular}{|c|c|c|c|c|c|c|c|}
\hline \multicolumn{8}{|c|}{ جدول(1): عينة البحث } \\
\hline \multirow{2}{*}{ المرتبة } & \multicolumn{2}{|c|}{ المجموع } & \multicolumn{2}{|c|}{ الإناث } & \multicolumn{2}{|c|}{ لذكور } & \multirow[t]{2}{*}{ الجنس } \\
\hline & $\%$ & ت & $\%$ & ت & $\%$ & ت & \\
\hline الأولى & 64 & 34 & 19 & 10 & 45 & 24 & القانون \\
\hline \multirow[t]{2}{*}{ الثانية } & 36 & 19 & 11 & 6 & 25 & 13 & العلوم السياسية \\
\hline & 100 & 53 & 30 & 16 & 70 & 37 & المجموع \\
\hline
\end{tabular}

تحديد المفاهيم و المصطلحات:

الدور: يُقصد به المساهمة الملموسة، سلباً أو إيجاباً، التي تقدمها الإعلام الكردي في تشكيل الرأي العام

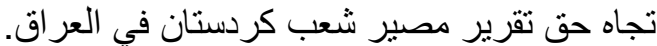

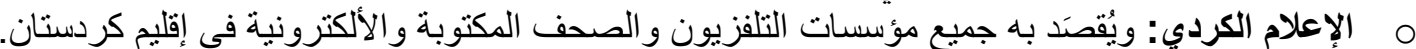

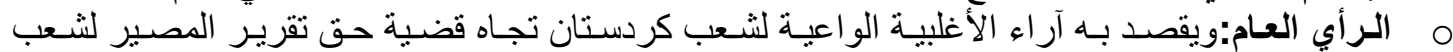

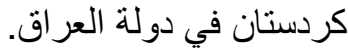

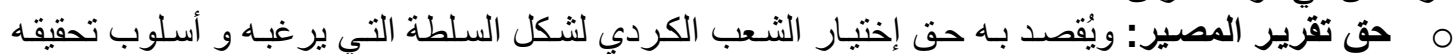

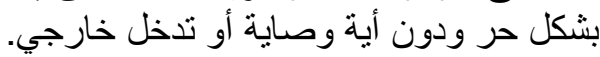
م شبع كردستان:ويقصد به الثعب الكردي القاطن في إقليم كردستان العر اق الناطق بلغته القومية، أي اللغنة الكردية، التي هي من فروع اللغات الهندوأوربية، و البالغ عدده أكثر من (6) ملايين نسمة.

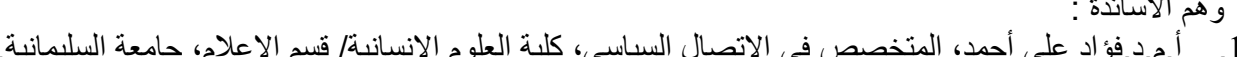
2.

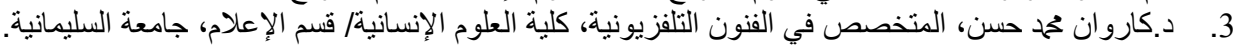




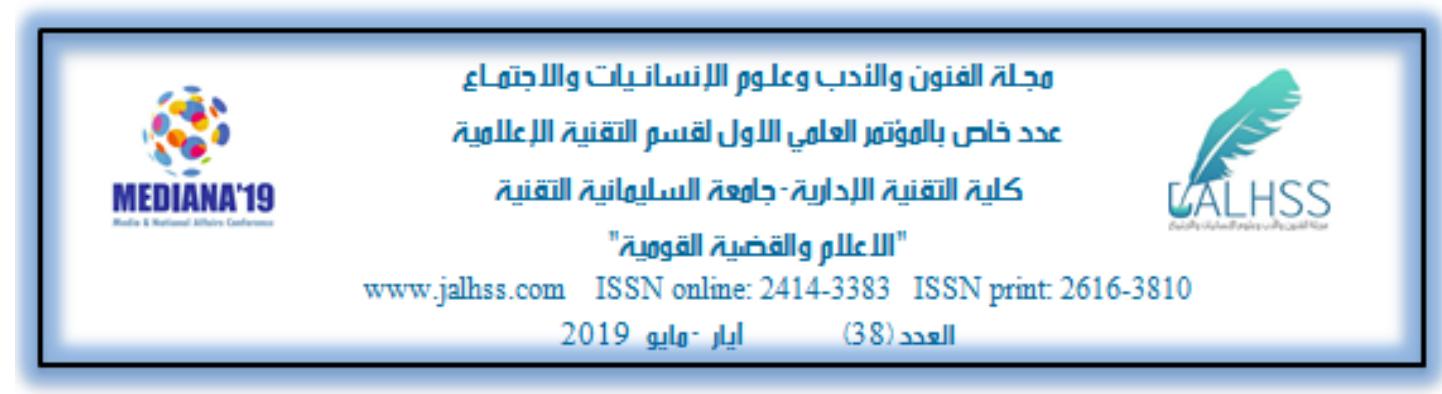

\section{الفصل الثاني: الإطار النظري للبحث}

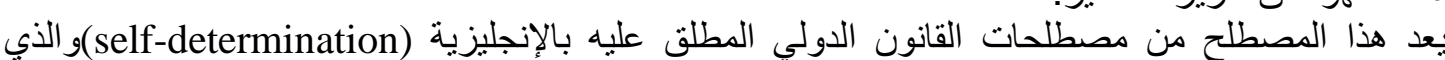

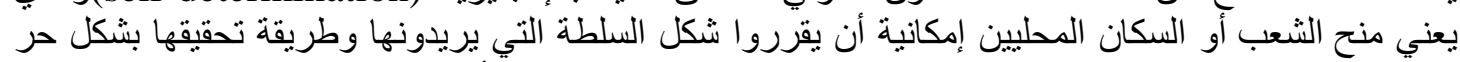

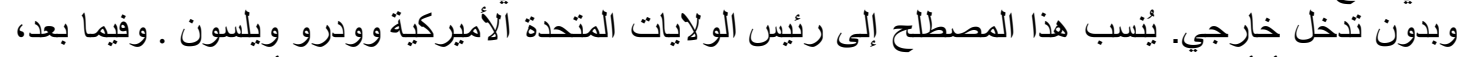

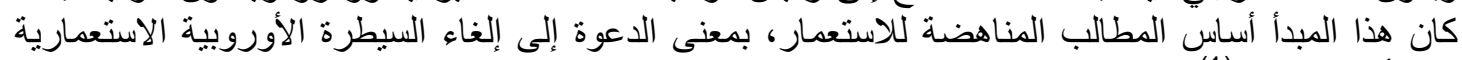
على أفريقيا وآسيا(1).

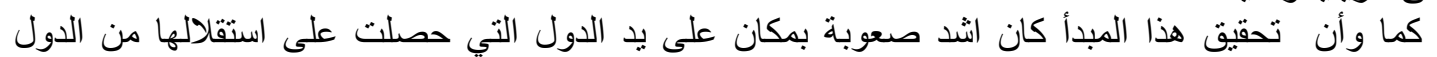

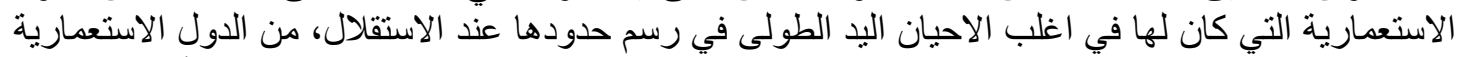

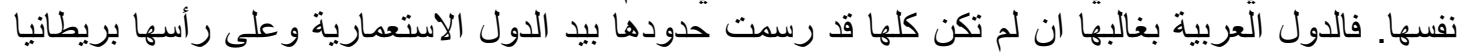

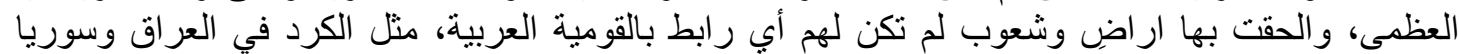

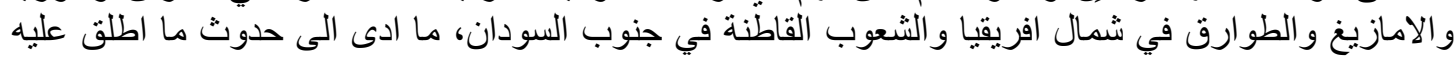

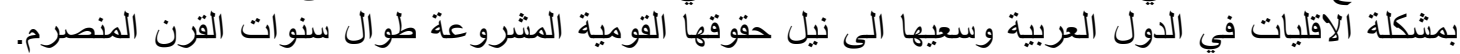

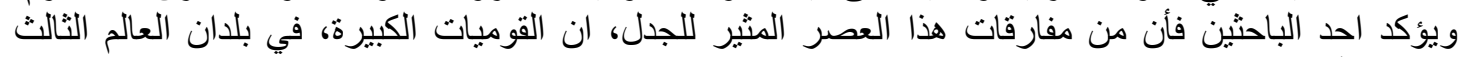

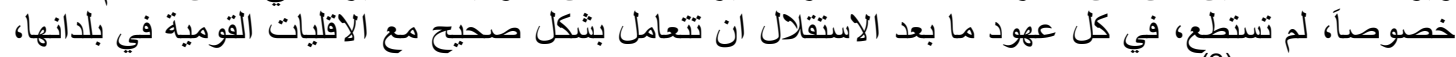

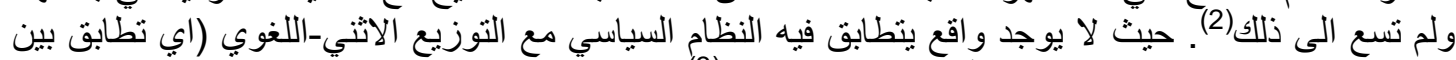

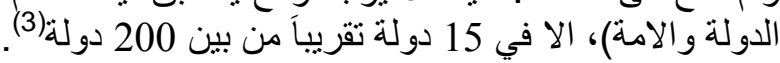

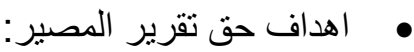

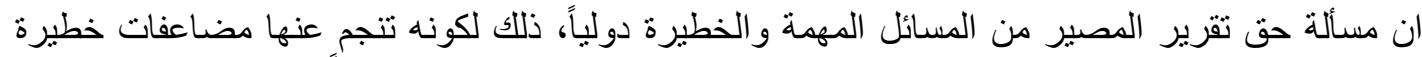

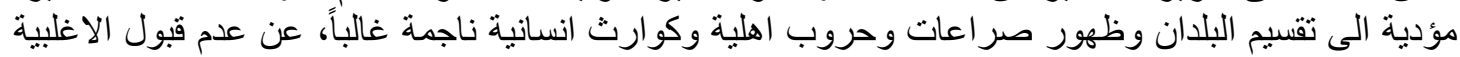

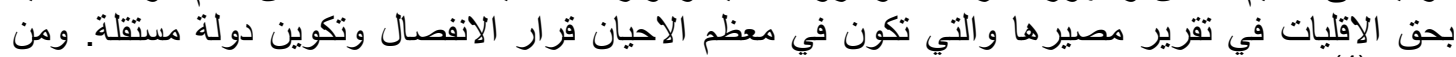

أهدافه:(4) الاقليات

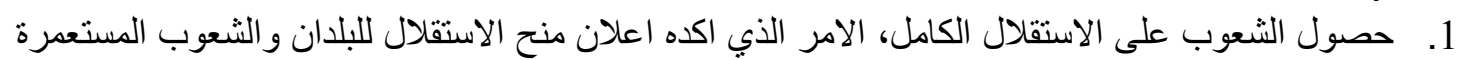

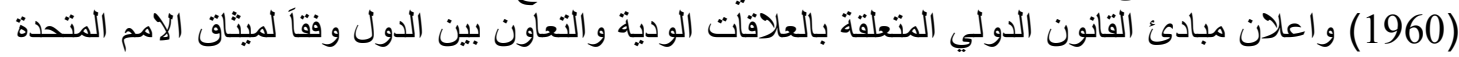

2. المحافظة على الاستقلال القائم على الار ادة الحقيقية و الحرة للشعب.

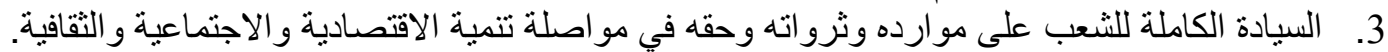
كما جاء في المادة الاولى من القسم الاول في الاتفاقية الدولية بشأن الحقوق الكية المدنية والسياسية لعادية لعام 1966،

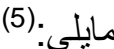
1. "لكافة الثعوب الحق في تقرير الدصير. ولها، استنادا لهذا الحق، ان تقرر بحرية كيانها السياسي وان

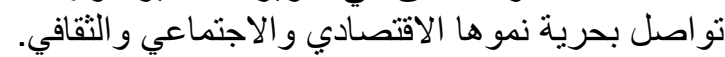

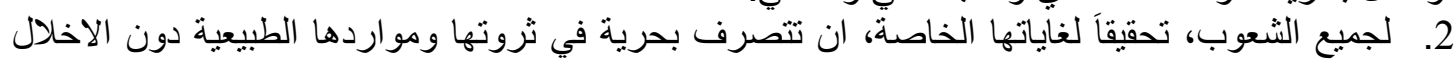

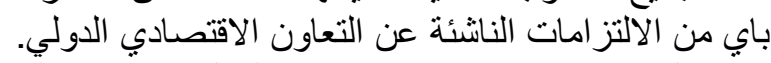

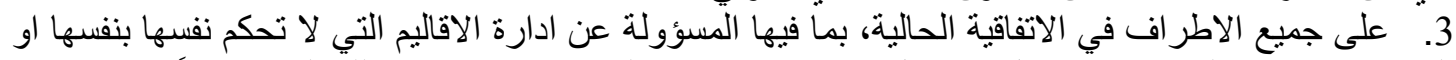

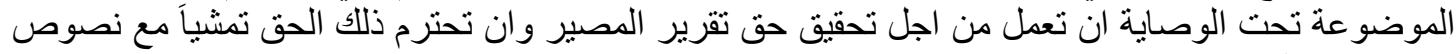

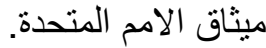

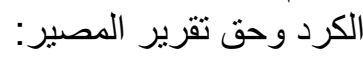

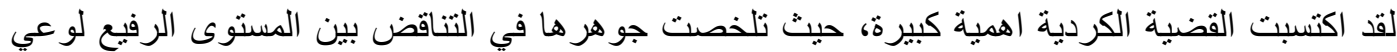

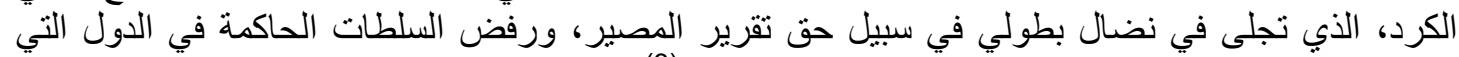

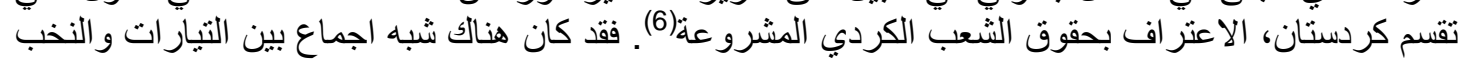




\section{هجلة الفنون والأدب وعلوم اللإنسانيات واللاجتهـاع \\ عدد خام بالمؤتمر العلميا اللاول لقسم التقنية اللاعلامية كلية التقنية اللإرابة-جامعت السليمانية التقنية}

MEDIANA'19

"اللاعلام والقضية القومية"

www.jalhss.com ISSN online: 2414-3383 ISSN print: 2616-3810

العدد (38) ايار -هايو 2019

السياسية و التقافية، على مستوى السلطات الرسمية و على مستوى الاحزاب و المؤسسات، الاجماع على رفض الاقرار

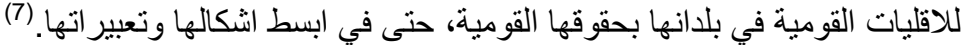

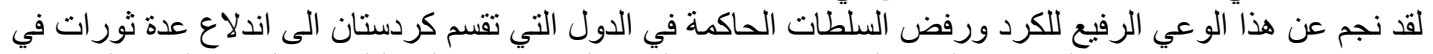

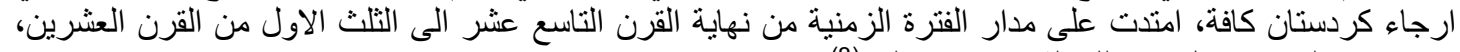

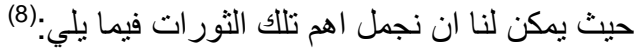

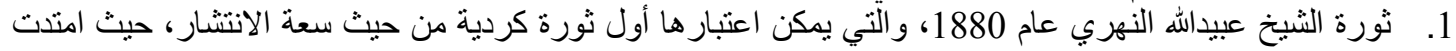

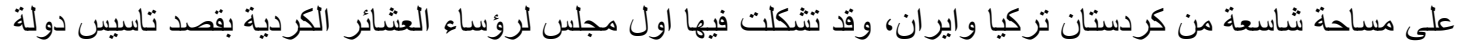

كردستان.

2. وتورة الثيخ محمود الحفيد في مايس 1919 و التي اعلن فيها قيام مملكة كردستان.

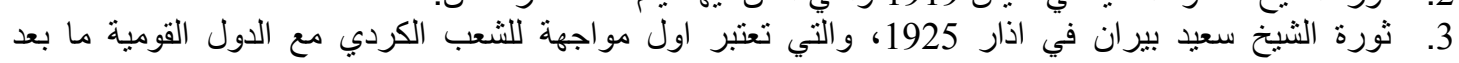

الاستعمار.

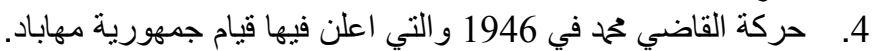

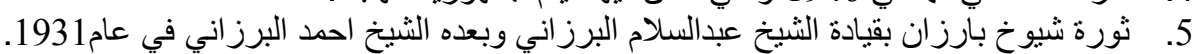

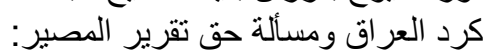

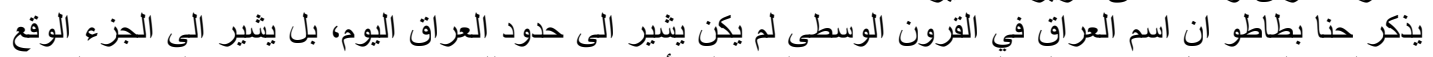

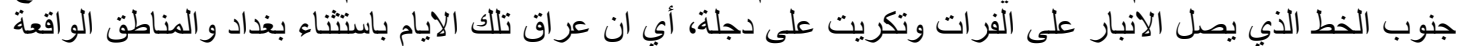

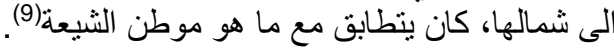

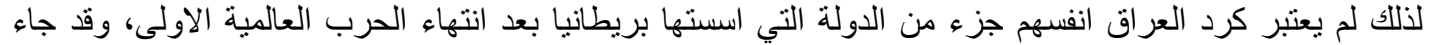

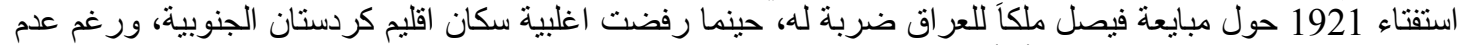

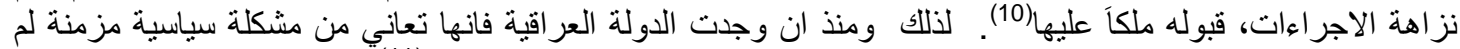

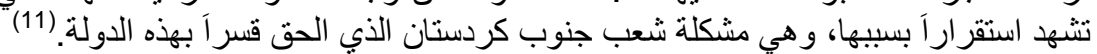

\section{الفصل الثالث: نتائج الدراسة الميدانية}

بعد متابعة ردود المبحوثين على أسئلة الإستبانة ونرجمتها إلى لغة الأرقام وتتظيمها وتبويها من خلال مست مستويات

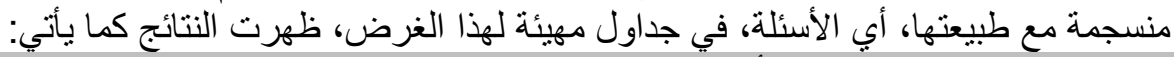

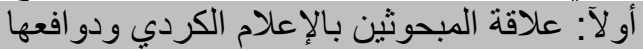

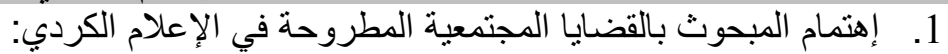

تشير النتائج بأن غالبية المبحوثين، يهتمون بقضايا المجتمع، وهم في المرتبة الأولى، ويليه الئهم الذين يهتمون

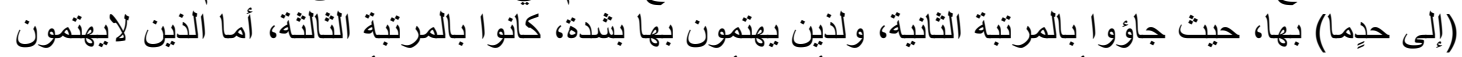

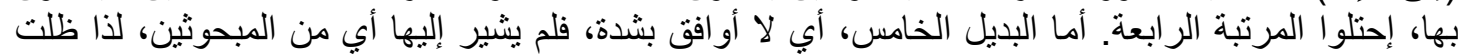

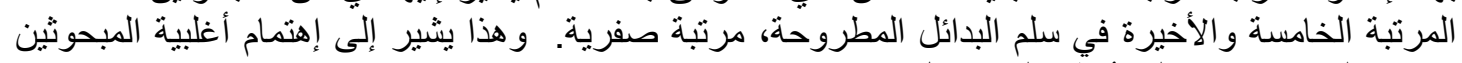

بقضايا المجتمع ومشاكله. يُنظٍر إلى جدول الى (3).

\begin{tabular}{|c|c|c|c|c|c|c|c|}
\hline \multicolumn{8}{|c|}{ جدول (2): إهتمام المبحوثين بقضايا المجتمع. } \\
\hline \multirow[b]{2}{*}{ المرتبة } & \multirow[b]{2}{*}{$\%$} & \multirow[b]{2}{*}{ المجموع } & \multicolumn{2}{|c|}{ الإناث } & \multicolumn{2}{|c|}{ الذكور الذـ } & \multirow[b]{2}{*}{ البدائل } \\
\hline & & & $\%$ & ت & $\%$ & $ت$ & \\
\hline الثالثة & 19 & 10 & 2 & 1 & 17 & 9 & أوافق جداً \\
\hline 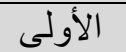 & 47 & 25 & 17 & 9 & 30 & 16 & أو افق \\
\hline الثانية & 26 & 14 & 9 & 5 & 17 & 9 & إلى حدٍ ما \\
\hline الر ابعة & 8 & 4 & 2 & 1 & 6 & 3 & لا أوافق \\
\hline الخامسة & 0 & 0 & 0 & 0 & 0 & 0 & لا أوافق جداً \\
\hline & 100 & 53 & 30 & 16 & 70 & 37 & المجموع الكلى \\
\hline
\end{tabular}




\section{مجلة الفنون والندب وعلوم اللإنسانيات واللاجتهاع \\ عدد خام بالمؤتمر العلمي اللاول القسم التقنية اللعاعلامية كلية التقنية اللإدارية-جامعت السليمانية التقنية}

"اللاعلام والقفية القومية"

www.jalhss.com ISSN online: 2414-3383 ISSN print: 2616-3810

\section{العدد (38) ايار -هايو}

2. العلاقة بين المبحوثين و الصحافة المكتوبة و الألكترونية الكردية:

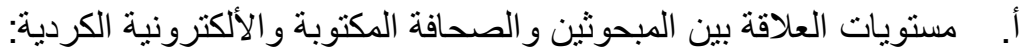

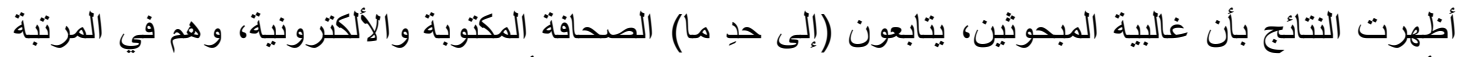

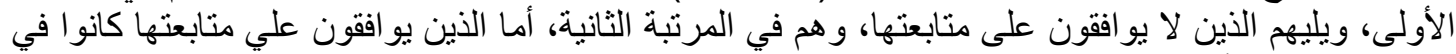

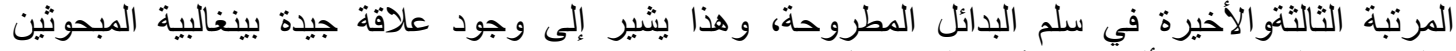

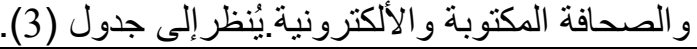

\begin{tabular}{|c|c|c|c|c|c|c|c|}
\hline \multicolumn{8}{|c|}{ جدول(3): مستويات العلاقة بين المبحوثين و الصحافة المكتوبة والألكترونية الكردية. } \\
\hline \multirow{2}{*}{ 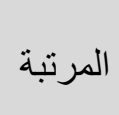 } & \multirow{2}{*}{$\%$} & \multirow{2}{*}{ 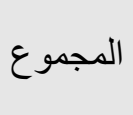 } & \multicolumn{2}{|c|}{ 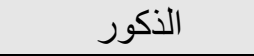 } & \multicolumn{2}{|c|}{ 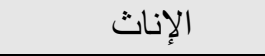 } & \multirow{2}{*}{ 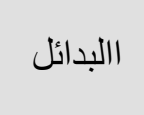 } \\
\hline & & & $\%$ & ت & $\%$ & ت & \\
\hline الثالثة & 22.64 & 12 & 18.87 & 10 & 3.78 & 2 & 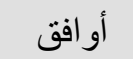 \\
\hline 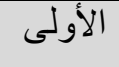 & 47.17 & 25 & 33.96 & 18 & 13.21 & 7 & 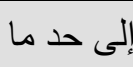 \\
\hline الثانية & 30.19 & 16 & 16.98 & 9 & 13.2 & 7 & 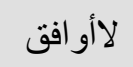 \\
\hline & 100 & 53 & 69.81 & 37 & 30.19 & 16 & المجموع \\
\hline
\end{tabular}

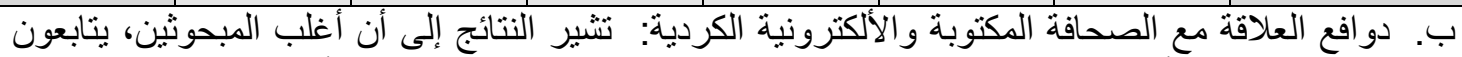

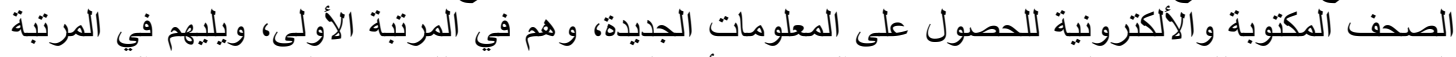

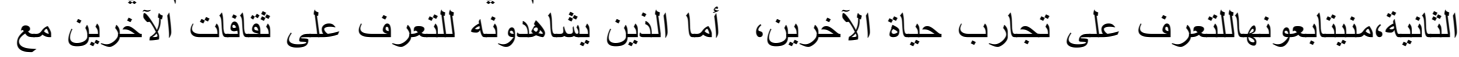

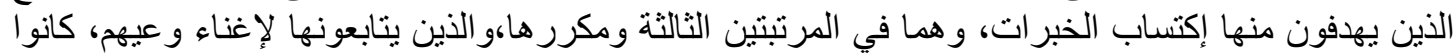

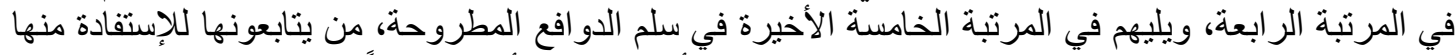

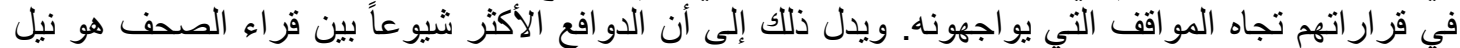
المعلومات و التعرف على تجارب الآخرين يُنظر إلى جدول(4).

\begin{tabular}{|c|c|c|c|c|c|c|c|c|c|c|c|c|c|}
\hline \multicolumn{14}{|c|}{ جدول(4) دو افع قراءة الصحف الكردية من قِبِل المبحوثين. } \\
\hline \multirow[b]{2}{*}{ 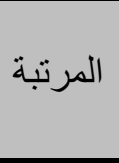 } & \multicolumn{4}{|c|}{ 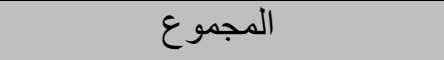 } & \multicolumn{4}{|c|}{ ل ل أو افق } & \multicolumn{4}{|c|}{ 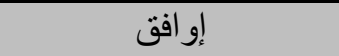 } & \multirow[t]{2}{*}{ 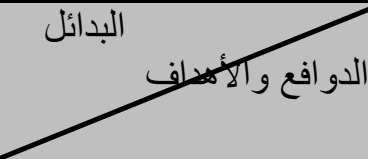 } \\
\hline & $\%$ & أو افق & $\%$ & 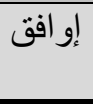 & $\%$ & نث & $\%$ & j & $\%$ & ن تث & $\%$ & j & \\
\hline 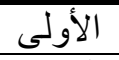 & 9 & 5 & 91 & 48 & 6 & 3 & 4 & 2 & 25 & 13 & 66 & 35 & الحصول على المعلومات. \\
\hline 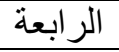 & 28 & 15 & 72 & 38 & 13 & 7 & 15 & 8 & 17 & 9 & 55 & 29 & إغناء الوعي \\
\hline 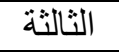 & 24 & 13 & 75.5 & 40 & 9 & 5 & 15 & 8 & 30 & 16 & 45 & 24 & التعرف على الثقافات \\
\hline الثالثة /م & 24 & 13 & 75.5 & 40 & 9 & 5 & 15 & 8 & 21 & 11 & 55 & 29 & إكتساب الخبرات \\
\hline 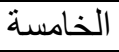 & 32 & 17 & 68 & 36 & 9 & 5 & 23 & 12 & 21 & 11 & 47 & 25 & المساعدة في إتخاذ القرار \\
\hline \multirow[t]{3}{*}{ 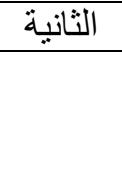 } & 15 & 8 & 85 & 45 & 6 & 3 & 9 & 5 & 25 & 13 & 60 & 32 & التعرف على تجارب الحياة \\
\hline & 23 & 12 & 77 & 41 & 9 & 5 & 14 & 7 & 23 & 12 & 55 & 29 & معدل التكرار ات و النسب \\
\hline & & 00 & \multicolumn{2}{|c|}{53} & \multicolumn{9}{|c|}{ المجموع الكلي لمعدل التكرارات ونسبها } \\
\hline
\end{tabular}


هجلة الفنون واللندب وعلوم اللإنسانيات واللاجِهـاعِ

عدد خلم بالهوتمر العلمي اللاول لقسم التقنية اللاعلامية

كلية التقنية اللدازية -جاهعت السليمانية التقنية

"

www.jalhss.com ISSN online: $2414-3383$ ISSN print $2616-3810$

2019 العدي

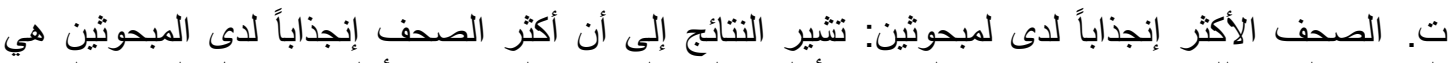

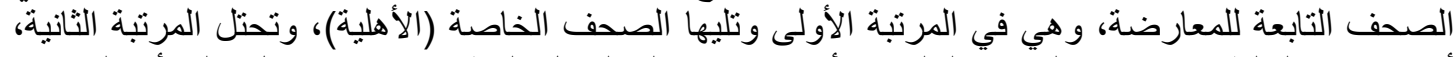

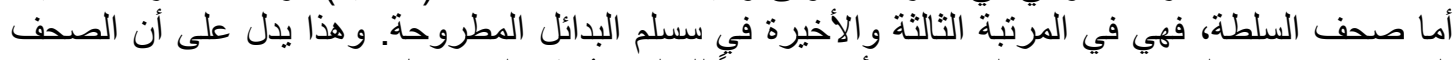

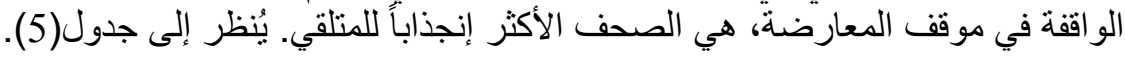

\begin{tabular}{|c|c|c|c|c|c|c|c|}
\hline \multicolumn{8}{|c|}{ جدول(5): الصحف الأكثر إنجذاباً لدى لمبحوثين. } \\
\hline \multirow{2}{*}{ 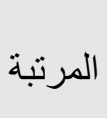 } & \multirow{2}{*}{$\%$} & \multirow{2}{*}{ 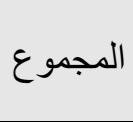 } & \multicolumn{2}{|c|}{ 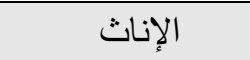 } & \multicolumn{2}{|c|}{ 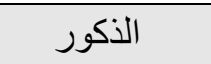 } & \multirow{2}{*}{ 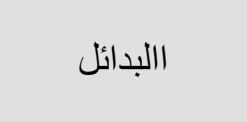 } \\
\hline & & & $\%$ & ت ت ت & $\%$ & ت ت & \\
\hline 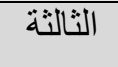 & 7.6 & 4 & 1.9 & 1 & 5.7 & 3 & صحف السلطة \\
\hline 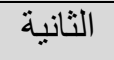 & 35.8 & 19 & 11.3 & 6 & 24.5 & 13 & صحف خاصة \\
\hline 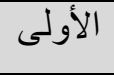 & 56.6 & 30 & 17 & 9 & 39.6 & 21 & صحف المعارضة \\
\hline & 100 & 53 & 30.2 & 16 & 69.8 & 37 & 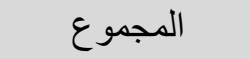 \\
\hline
\end{tabular}

3. العلاقة بين المبحوثين و التلفزيون: أ. ـ مستويات العلاقة بين المبحوثين و التين التلفزيون الكردي:

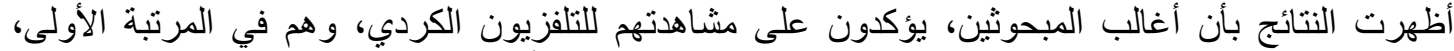

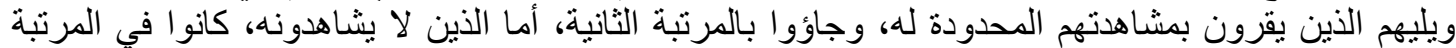

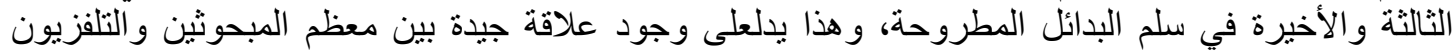

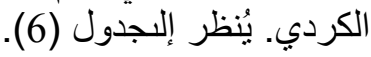

\begin{tabular}{|c|c|c|c|c|c|c|c|}
\hline \multicolumn{8}{|c|}{ جدول(6): مستويات العلاقة بين المبحوثين و التلفزيون الكردي. } \\
\hline \multirow{2}{*}{ 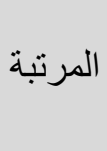 } & \multirow{2}{*}{$\%$} & \multirow{2}{*}{ 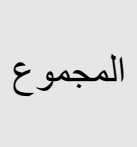 } & \multicolumn{2}{|c|}{ الإناث } & \multicolumn{2}{|c|}{ 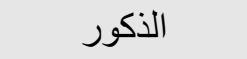 } & \multirow{2}{*}{ البدائل } \\
\hline & & & $\%$ & $ت$ & $\%$ & $ت$ & \\
\hline 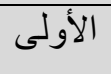 & 45 & 24 & 17 & 9 & 28.3 & 15 & 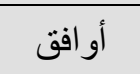 \\
\hline 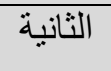 & 42 & 22 & 7.55 & 4 & 34 & 18 & 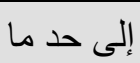 \\
\hline الثالثة & 13 & 7 & 5.66 & 3 & 7.55 & 4 & ل لأو افق \\
\hline & 100 & 53 & 30.2 & 16 & 69.8 & 37 & المجموع \\
\hline
\end{tabular}

ث. دوافع العلاقة مع التلفزيون الكردي:

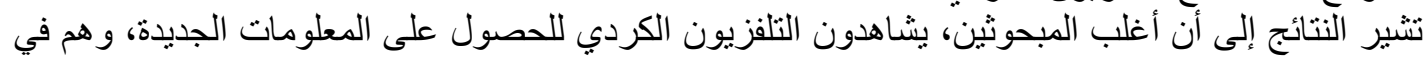

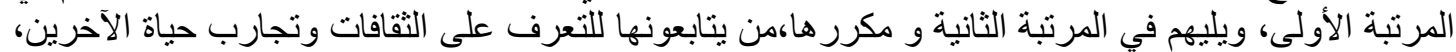

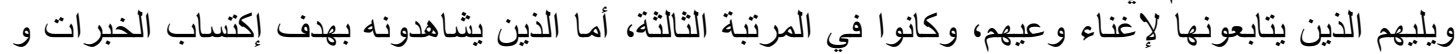

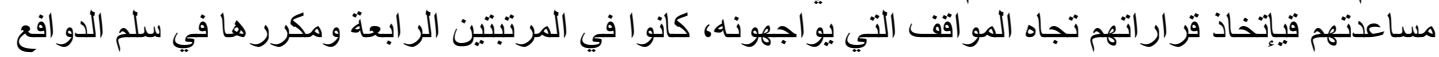




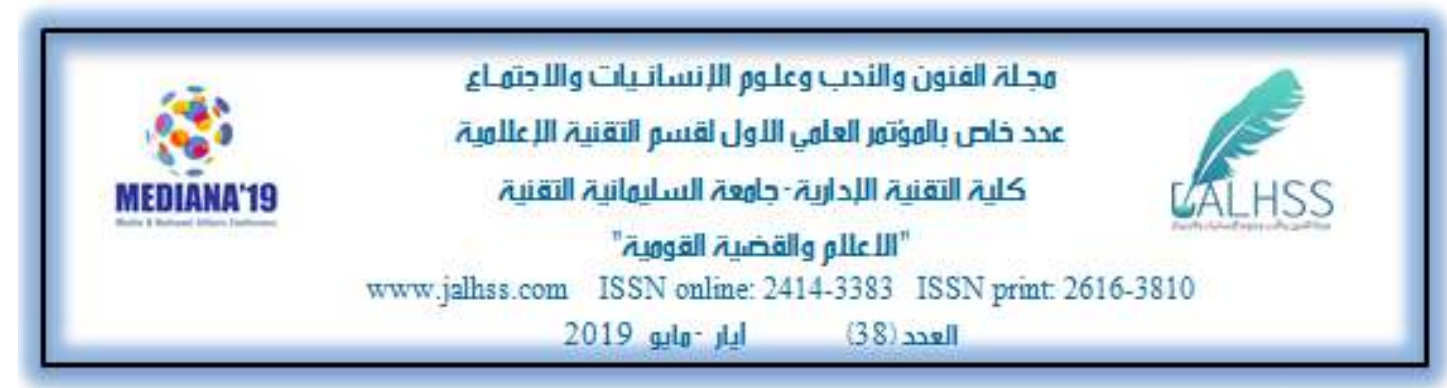

المطروحة. ويشير ذللك إلى أن الدوافع الأكثر شيوعاً بين مشاهدي التلفزيون هي الحصول عل المعلومات

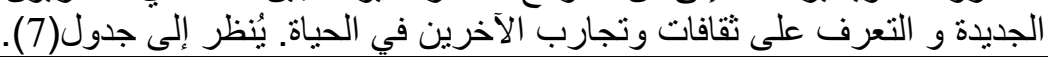

جدول(7) دو افع مشاهدة المبحوثين للتلفزيون الكردي.

\begin{tabular}{|c|c|c|c|c|c|c|c|c|c|c|c|c|c|}
\hline \multirow[b]{2}{*}{ المرتبة } & \multicolumn{4}{|c|}{ المجموع } & \multicolumn{4}{|c|}{ لا لأو افق } & \multicolumn{4}{|c|}{ إوافق } & \multirow[t]{2}{*}{ البدائل } \\
\hline & $\%$ & $\begin{array}{c}\text { أو افق } \\
\text { أل }\end{array}$ & $\%$ & إو افق & $\%$ & نث & $\%$ & ذ & $\%$ & نث & $\%$ & $\dot{j}$ & \\
\hline الأولى & 6 & 3 & 94 & 50 & 4 & 2 & 2 & 1 & 26 & 14 & 68 & 36 & الحصول على المعلومات. \\
\hline الثالثة & 24 & 13 & 76 & 40 & 11 & 6 & 13 & 7 & 19 & 10 & 57 & 30 & إغناء الوعي \\
\hline الثانية & 17 & 9 & 83 & 44 & 6 & 3 & 11 & 6 & 25 & 13 & 58 & 31 & التعرف على الثقافات \\
\hline الر ابعة & 26 & 14 & 74 & 39 & 11 & 6 & 15 & 8 & 19 & 10 & 55 & 29 & إكتساب الخبرات \\
\hline الر ابعة،هم & 27 & 14 & 74 & 39 & 6 & 3 & 21 & 11 & 25 & 13 & 49 & 26 & المساعدة في إتخاذ القرار \\
\hline \multirow[t]{3}{*}{ الثانية/م } & 17 & 9 & 83 & 44 & 8 & 4 & 9 & 5 & 23 & 12 & 60 & 32 & التعرف على تجارب الحياة \\
\hline & & 10 & 81 & 43 & 8 & 4 & 12 & 6 & 23 & 12 & 58 & 31 & معدل التكر ارات و النسب \\
\hline & & 00 & & 3 & \multicolumn{9}{|c|}{ المجموع الكلي لمعدل التكرار ات ونسبها } \\
\hline
\end{tabular}

ج. التلفزيون الأكثر إنجذاباً لدى لمبحوثين:

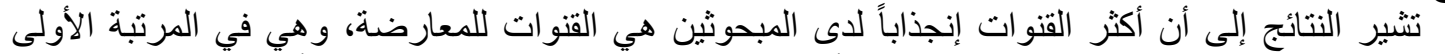

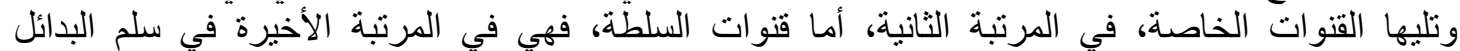

المطروحة. يُنظر إلى جدول(8).

\begin{tabular}{|c|c|c|c|c|c|c|c|}
\hline \multicolumn{8}{|c|}{ جدول(8): التلفزيون الأكثر إنجذاب أللمبحوثين. } \\
\hline \multirow[b]{2}{*}{ 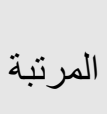 } & \multirow{2}{*}{$\%$} & \multirow{2}{*}{ 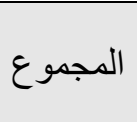 } & \multicolumn{2}{|c|}{ 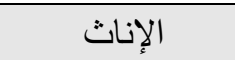 } & \multicolumn{2}{|c|}{ 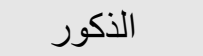 } & \multirow{2}{*}{ البدائل } \\
\hline & & & $\%$ & ت & $\%$ & 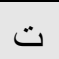 & \\
\hline 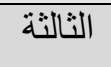 & 15 & 8 & 4 & 2 & 11 & 6 & قنوات السلطة \\
\hline الثانية & 34 & 18 & 11 & 6 & 23 & 12 & القنو ات الخاصة الخة \\
\hline 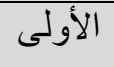 & 51 & 27 & 15 & 8 & 36 & 19 & قنو ات المعار ضة \\
\hline & 100 & 53 & 30 & 16 & 70 & 37 & 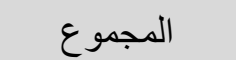 \\
\hline
\end{tabular}

ثانياً: التساؤلات المتعلقة بموضوع البحث:

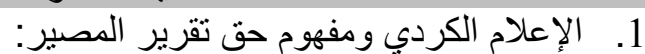



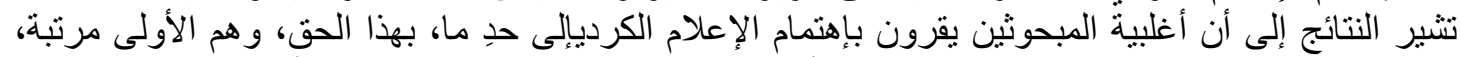

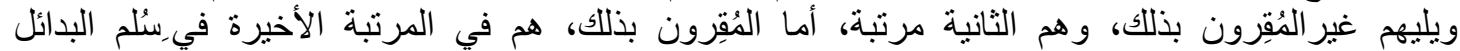

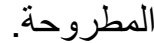
و هذا يدل على أن الإعلام الكردي لم يكن جدياً مع هذه القضية المهمة عند الكرد. يُنظر إلى جدول(9). 
مجِلة الفنون واللندب وعلوم اللإنسانيات واللاجِهـاع

عدد خلم بالهوتمر العلمي اللاول لقسر التقنية اللاعلامية

كلية التقنية اللدازية -جامعت السليمانية التقنية

"

www.jalhss.com ISSN online: $2414-3383$ ISSN print $2616-3810$

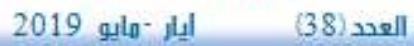

\begin{tabular}{|c|c|c|c|c|c|c|c|}
\hline \multicolumn{8}{|c|}{ جدول( 9): الإهتمام الإعلامي المستمر بحق تقرير المصير وتخصيص مساحات زمكانية له. } \\
\hline 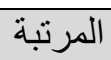 & $\%$ & 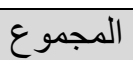 & $\%$ & 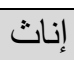 & $\%$ & ذكور & البدائل \\
\hline الثالثة & 6 & 3 & 2 & 1 & 4 & 2 & أو افق \\
\hline الأولى & 62 & 33 & 23 & 12 & 40 & 21 & إلى حذ ما \\
\hline الثانبة & 32 & 17 & 6 & 3 & 26 & 14 & لا لأوافق \\
\hline & 100 & 53 & 30 & 16 & 70 & 37 & المحمو ع \\
\hline
\end{tabular}

ب. نشر الإعلام الكردي لمعلومات شاملة و دقبقة عن مفهوم حق تقرير المصير و تفاصيلها.

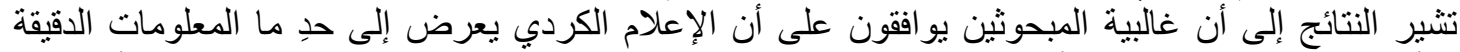

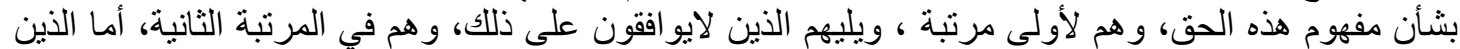

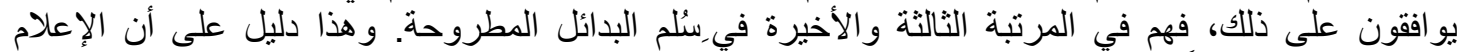

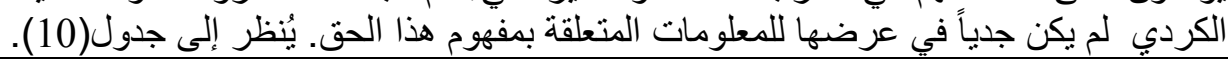

\begin{tabular}{|c|c|c|c|c|c|c|c|}
\hline \multicolumn{8}{|c|}{ جدول( 10): عرض معلومات دقيقة عن مفهوم حق تقرير المصير . } \\
\hline 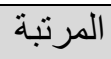 & $\%$ & 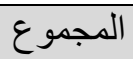 & $\%$ & إناث & $\%$ & ذكور & البدائل \\
\hline الثالثة & 4 & 2 & 2 & 1 & 2 & 1 & أو افق \\
\hline الأولى & 53 & 28 & 17 & 9 & 36 & 19 & إلى حد ما \\
\hline الثانية & 43 & 23 & 11 & 6 & 32 & 17 & لا أو افق \\
\hline & 100 & 53 & 30 & 16 & 70 & 37 & المجمو و \\
\hline
\end{tabular}

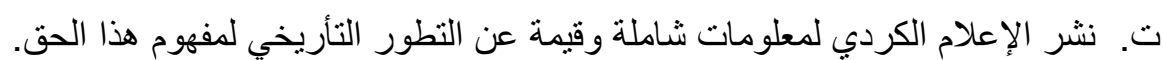

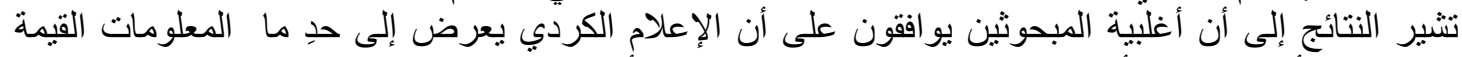

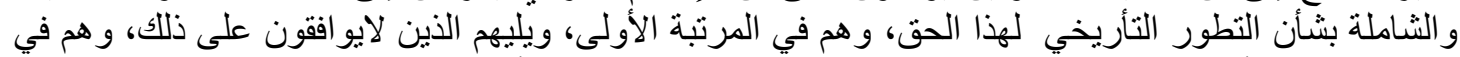

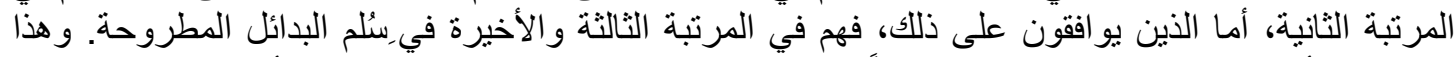

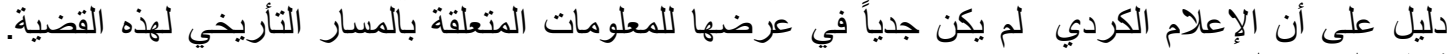

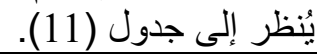

\begin{tabular}{|c|c|c|c|c|c|c|c|}
\hline \multicolumn{8}{|c|}{ جدول( 11 ): عرض معلومات شاملة وقيمةعن التطور التأريخي لمفهوم حق تقرير المصير . } \\
\hline المرتبة & $\%$ & 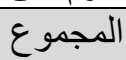 & $\%$ & إناث & $\%$ & ذكور & البدائل \\
\hline الثالثة & 6 & 3 & 4 & 2 & 2 & 1 & أو افق \\
\hline الأولى & 49 & 26 & 15 & 8 & 34 & 18 & 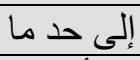 \\
\hline الثانية & 45 & 24 & 13 & 7 & 32 & 17 & لا أو افق \\
\hline & 100 & 53 & 32 & 17 & 68 & 36 & المجمو ع \\
\hline
\end{tabular}

ث. نشر الإعلام الكردي لمعلومات دقيقة عن الأبعاد البنيوية لمفهوم حق تقرير المصبير.

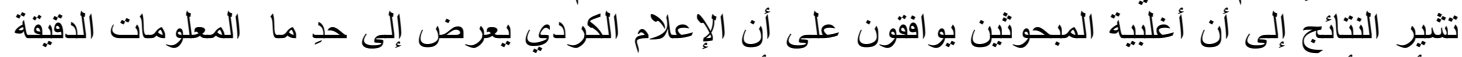

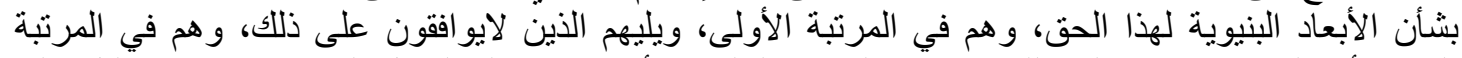

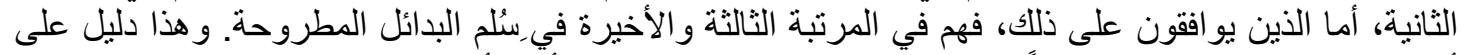

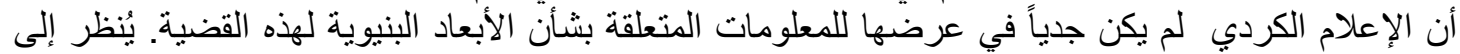

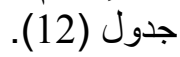




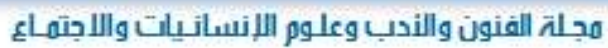

عدد خلم بالهوتمر العلمي اللاول لقسر التقنية اللاعلامية

كلية التقنية اللدازية -جامعت السليمانية التقنية

"

www.jalhss.com ISSN online: $2414-3383$ ISSN print $2616-3810$

العدد

\begin{tabular}{|c|c|c|c|c|c|c|c|}
\hline \multicolumn{8}{|c|}{ جدول(12 ): عرض معلومات دقيقة عن الأبعاد البنيوية لمفهوم حق تقرير المصير. } \\
\hline المرتبة & $\%$ & 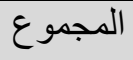 & $\%$ & 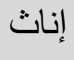 & $\%$ & ذكور & البدائل \\
\hline الثالثة & 4 & 2 & 2 & 1 & 2 & 1 & أو افق \\
\hline 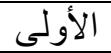 & 49 & 26 & 19 & 10 & 30 & 16 & 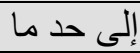 \\
\hline الثانية & 47 & 25 & 9 & 5 & 38 & 20 & لا أو افق \\
\hline & 100 & 53 & 30 & 16 & 70 & 37 & 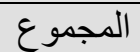 \\
\hline
\end{tabular}

ج. نشر الإعلام الكردي لمعلومات دقيقة عن الأبعاد القانونية لمفهوم حق تقرير المصير.

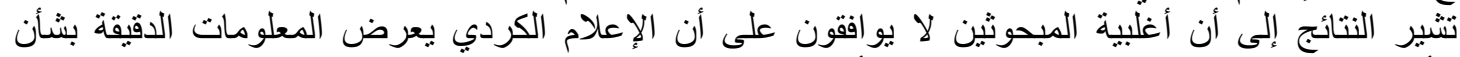

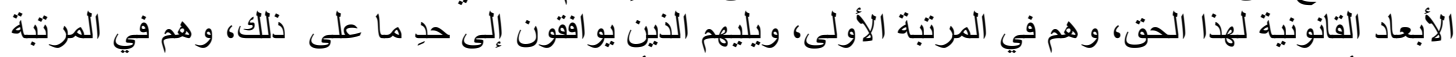

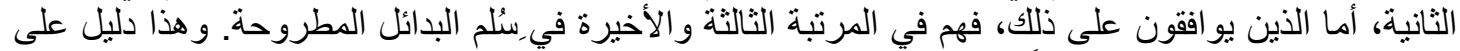

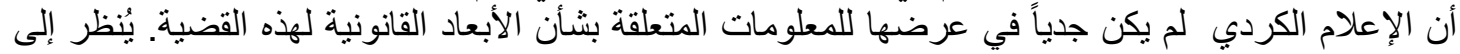

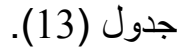

\begin{tabular}{|c|c|c|c|c|c|c|c|}
\hline \multicolumn{8}{|c|}{ جدول(13 ): عرض معلومات دقيقة عن الأبعاد القانونية لمفهوم حق تقرير المصير. } \\
\hline المرتبة & $\%$ & 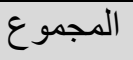 & $\%$ & إناث & $\%$ & ذكور & البدائل \\
\hline الثالثة & 8 & 4 & 4 & 2 & 4 & 2 & أو افق \\
\hline 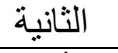 & 41 & 22 & 15 & 8 & 26 & 14 & 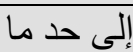 \\
\hline 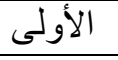 & 51 & 27 & 11 & 6 & 40 & 21 & لا أو افق \\
\hline & 100 & 53 & 30 & 16 & 79 & 37 & المجموع \\
\hline
\end{tabular}

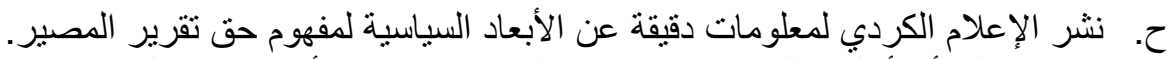

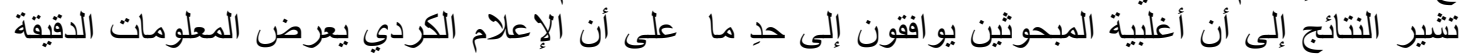

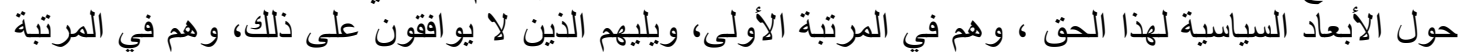

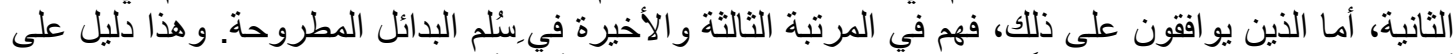

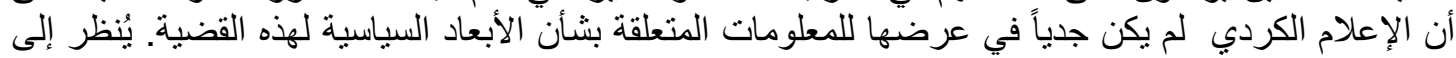

جدول (14).

\begin{tabular}{|c|c|c|c|c|c|c|c|}
\hline \multicolumn{8}{|c|}{ جدول(14 ): عرض معلومات دقيقة عن الأبعاد السياسية لمفهوم حق تقرير المصير. } \\
\hline المرتبة & $\%$ & المجموع & $\%$ & إناث & $\%$ & ذكور & البدائل \\
\hline الثالثة & 8 & 4 & 4 & 2 & 4 & 2 & أو افق \\
\hline 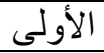 & 51 & 27 & 17 & 9 & 34 & 18 & 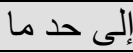 \\
\hline الثانية & 41 & 22 & 9 & 5 & 32 & 17 & لا لأو افق \\
\hline & 100 & 53 & 30 & 16 & 70 & 37 & 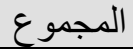 \\
\hline
\end{tabular}




\section{مجِ الفنون واللندب وعلوم اللإنسانِيات واللاجتِهـاع \\ عدد خام بالهونتمر العلهي اللاول لقسم التقنية اللـ عامية \\ كلية التقنية الليدارية-جامعت السليهانية التقنية}

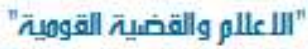

www.jalhss.com ISSN online: 2414-3383 ISSN print 2616-3810

2019 العدي

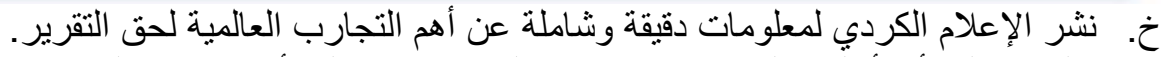

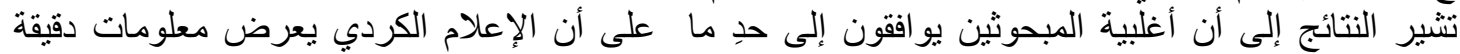

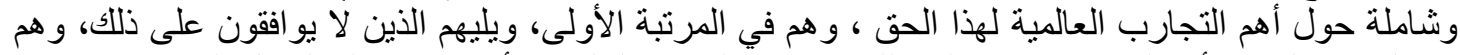

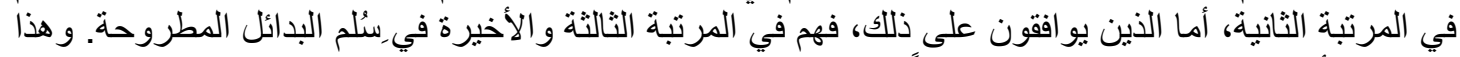

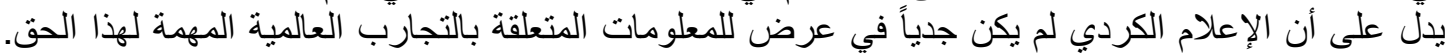

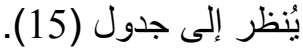

\begin{tabular}{|c|c|c|c|c|c|c|c|}
\hline \multicolumn{8}{|c|}{ جدول(15 ): عرض معلومات دقيقة عن أهم التجارب العالمية لحق تقرير المصير. } \\
\hline 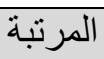 & $\%$ & 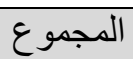 & $\%$ & إناث & $\%$ & ذكور & البدائل \\
\hline 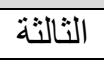 & 4 & 2 & 2 & 1 & 2 & 1 & أو افق \\
\hline الأولى & 49 & 26 & 19 & 10 & 30 & 16 & 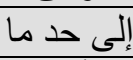 \\
\hline 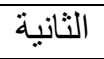 & 47 & 25 & 9 & 5 & 38 & 20 & لا أو افق \\
\hline & 100 & 53 & 30 & 16 & 70 & 37 & المجموع \\
\hline
\end{tabular}

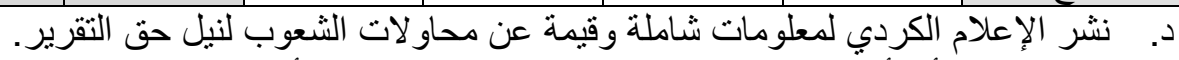

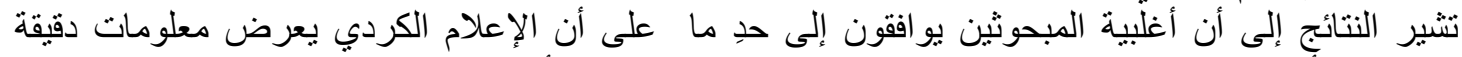

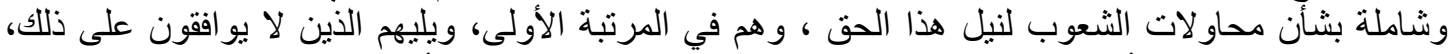

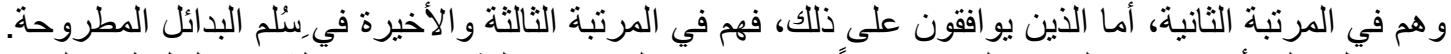

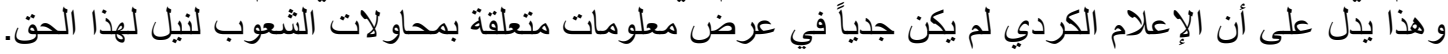

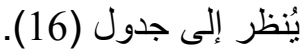

\begin{tabular}{|c|c|c|c|c|c|c|c|}
\hline \multicolumn{8}{|c|}{ جدول(16): عرض معلومات دقيقة عن محاو لات الشعوب لنيل الحق في تقرير مصيرها. } \\
\hline المرتبة & $\%$ & 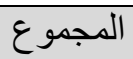 & $\%$ & إناث & $\%$ & ذكور & البدائل \\
\hline الثالثة & 8 & 4 & 6 & 3 & 2 & 1 & أو افق \\
\hline 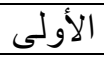 & 62 & 33 & 19 & 10 & 43 & 23 & 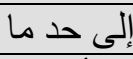 \\
\hline الثانية & 30 & 16 & 5 & 3 & 25 & 13 & لا لأو افق \\
\hline & 100 & 53 & 30 & 16 & 70 & 37 & 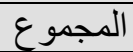 \\
\hline
\end{tabular}

2. در اسة الإعلام الكردي لحق تقرير مصير شعب كردستان إستقصائياً:

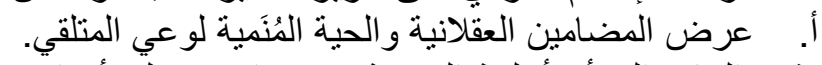

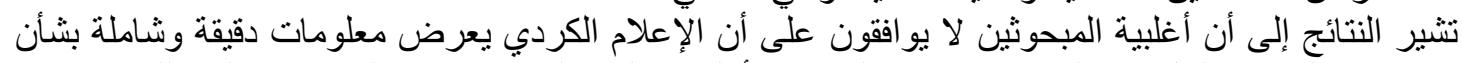

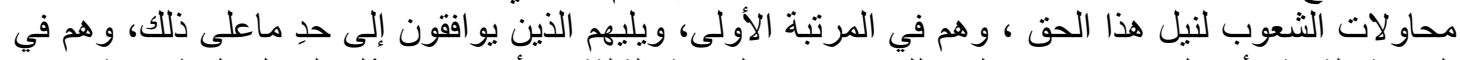

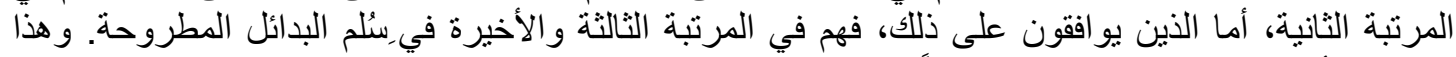

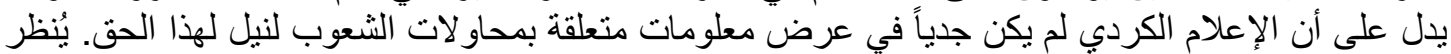

إلى جدول (17). 


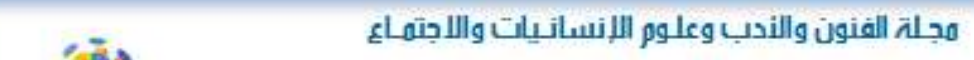

عدد خام بالمونتمر العلمي اللاول لقسم التقنية اللعاعلامية

MEDIANA'19 كلية التقنية اللدارية -جامعة السليمانية التقنية

"

www.jalhss.com ISSN online: $2414-3383$ ISSN print $2616-3810$

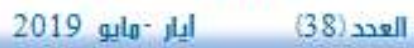

\begin{tabular}{|c|c|c|c|c|c|c|c|}
\hline \multicolumn{8}{|c|}{ جدول( 17): عرض الإعلام الكردي لمضامين حية وعقلانية عن حق تقرير المصير . } \\
\hline 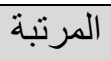 & $\%$ & 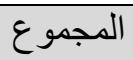 & $\%$ & إناث & $\%$ & ذكور & البدائل \\
\hline الثالثة & 4 & 2 & 2 & 1 & 2 & 1 & أو افق \\
\hline الثانية & 41 & 22 & 9 & 5 & 32 & 17 & 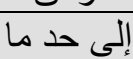 \\
\hline 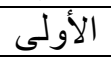 & 55 & 29 & 19 & 10 & 36 & 19 & لا أوافق \\
\hline & 100 & 53 & 30 & 16 & 70 & 37 & المجموع \\
\hline
\end{tabular}

ب. يهتم الإعلام الكردي بتوضيح الإبعاد الغامضة لحق تقرير مصير الكرد، بشكل مستمر.

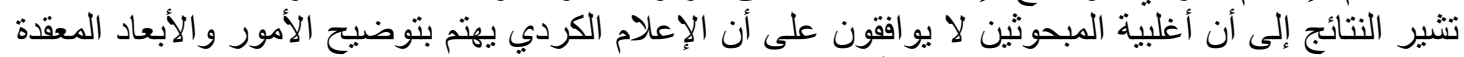

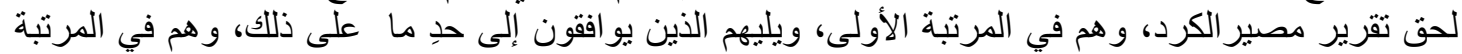

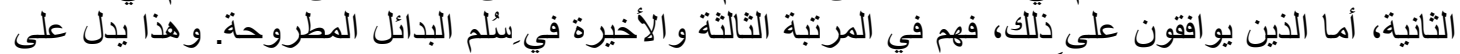

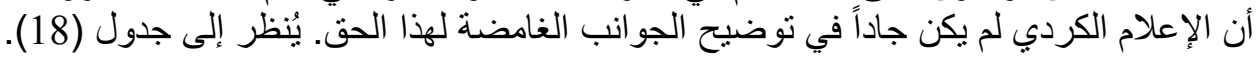

\begin{tabular}{|c|c|c|c|c|c|c|c|}
\hline \multicolumn{8}{|c|}{ جدول( 18): الإهتمام بتوضيح الأبعاد الغامضة لحق تقرير . } \\
\hline 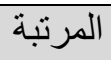 & $\%$ & المجموع & $\%$ & إناث & $\%$ & ذكور & البدائل \\
\hline 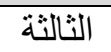 & 4 & 2 & 2 & 1 & 2 & 1 & أو افق \\
\hline 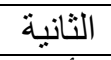 & 30 & 16 & 13 & 7 & 17 & 9 & 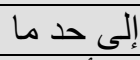 \\
\hline 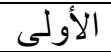 & 66 & 35 & 15 & 8 & 51 & 27 & لا لأو افق \\
\hline & 100 & 53 & 30 & 16 & 70 & 37 & المجموع \\
\hline
\end{tabular}

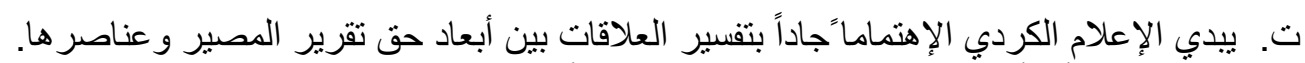

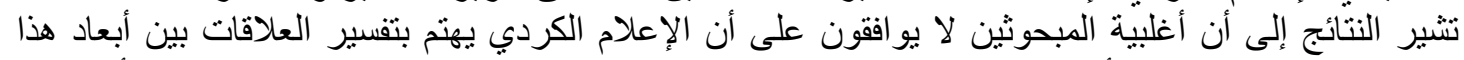

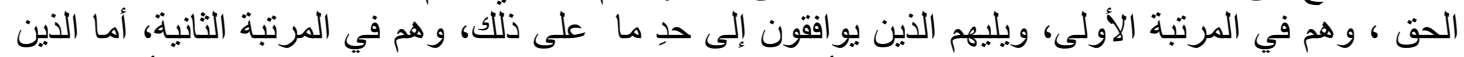

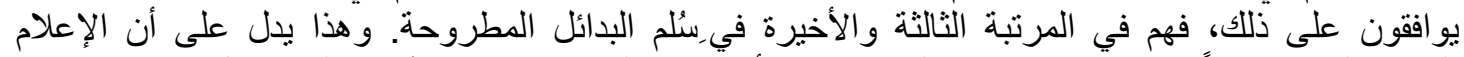

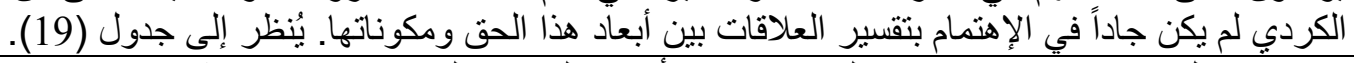

\begin{tabular}{|c|c|c|c|c|c|c|c|}
\hline \multicolumn{8}{|c|}{ جدول( 19): الإهتمام بتفسير العلاقات بين الأبعاد و العناصر لحق تقرير مصبر شعب كردستان . } \\
\hline 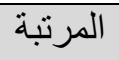 & $\%$ & 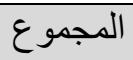 & $\%$ & إناث & $\%$ & ذكور & البدائل \\
\hline الثالثة & 4 & 2 & 2 & 1 & 2 & 1 & أو افق \\
\hline الثانية & 30 & 16 & 11 & 6 & 19 & 10 & 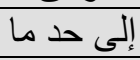 \\
\hline 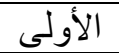 & 66 & 35 & 17 & 9 & 49 & 26 & لا أو افق \\
\hline & 100 & 53 & 30 & 16 & 70 & 37 & المجموع \\
\hline
\end{tabular}

ث. يبدي الإعلام الكردي إهتماماً مستمرً بتحليل العلاقات بين أبعاد حق تقرير المصبير و عناصرها.

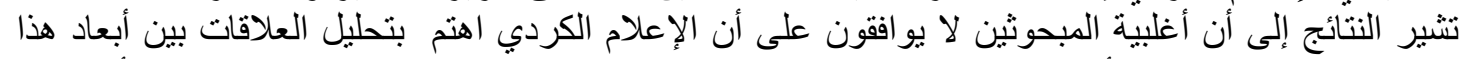

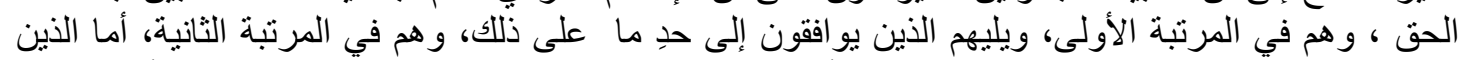

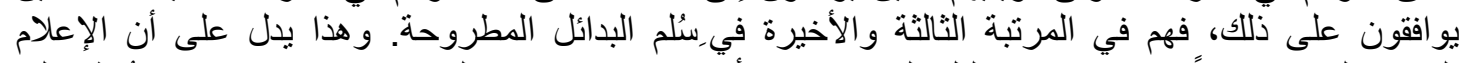

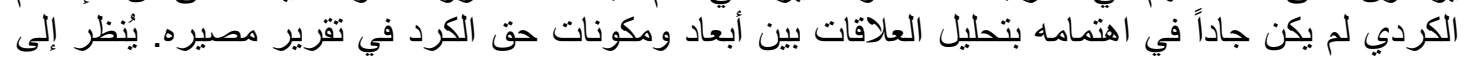

جدول (20). 


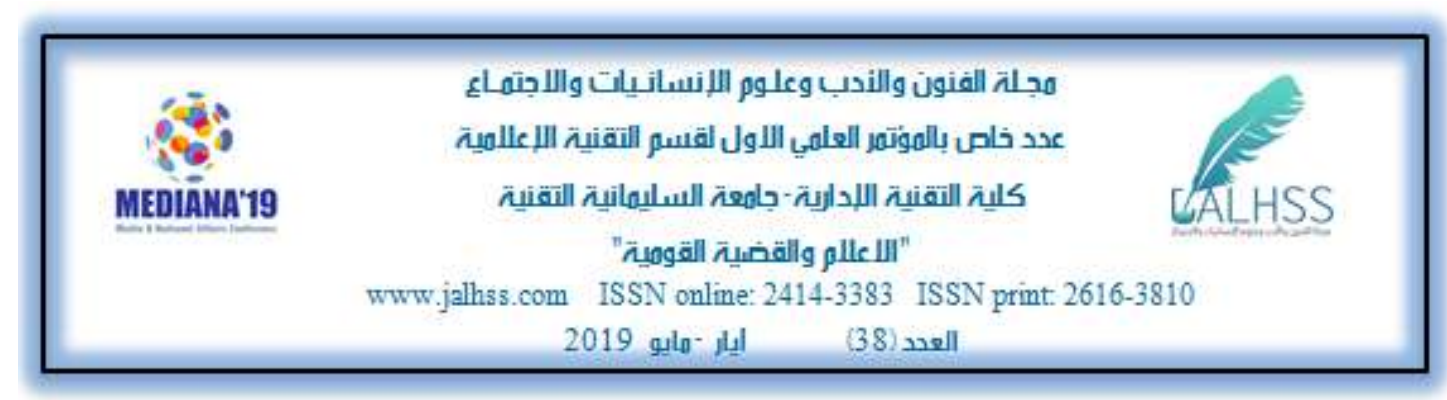

\begin{tabular}{|c|c|c|c|c|c|c|c|}
\hline \multicolumn{8}{|c|}{ جدول( 20): الإهتمام بتفسير العلاقات بين الأبعاد والعناصر لحق تقرير مصير شعب كردستان . } \\
\hline المرتبة & $\%$ & المجموع & $\%$ & إناث & $\%$ & ذكور & البدائل \\
\hline الثالثة & 4 & 2 & 2 & 1 & 2 & 1 & أو افق \\
\hline الثانية & 41 & 22 & 15 & 8 & 26 & 14 & 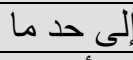 \\
\hline 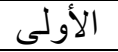 & 55 & 29 & 13 & 7 & 42 & 22 & لا أو افق \\
\hline & 100 & 53 & 30 & 16 & 70 & 37 & 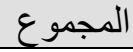 \\
\hline
\end{tabular}

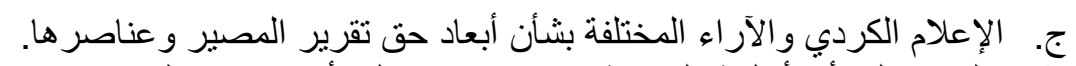

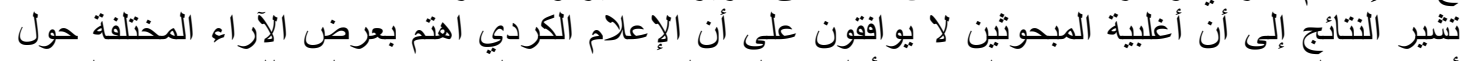

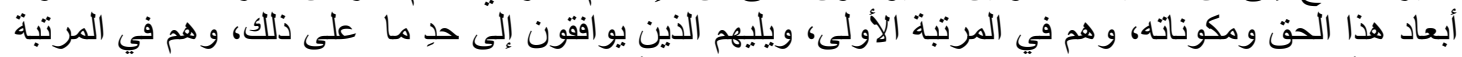

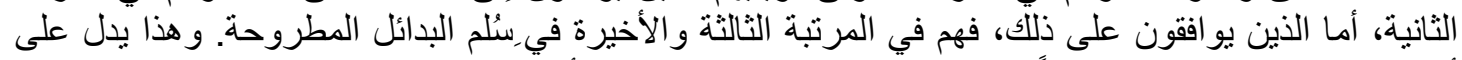

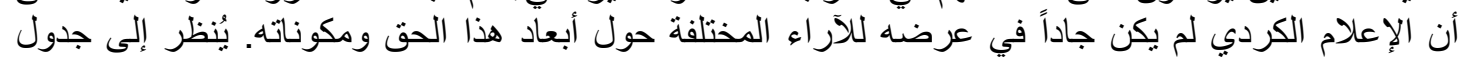

\begin{tabular}{|c|c|c|c|c|c|c|c|}
\hline \multicolumn{8}{|c|}{ جدول(21): عرض الإعلام الكردي للآر اء المختلفة بشأن أبعاد حق تقرير المصير و عناصر ها. } \\
\hline 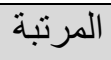 & $\%$ & 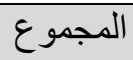 & $\%$ & إناث & $\%$ & ذكور & البدائل \\
\hline 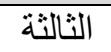 & 4 & 2 & 2 & 1 & 2 & 1 & أو افق \\
\hline الثانية & 38 & 20 & 17 & 9 & 21 & 11 & إلى حد ما \\
\hline 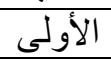 & 58 & 31 & 11 & 6 & 47 & 25 & لا أو افق \\
\hline & 100 & 53 & 30 & 16 & 70 & 37 & المجموع \\
\hline
\end{tabular}

ح. موضو عية الإعلام الكردي في تنتاوله لحق تقرير مصير شعب كردستان.

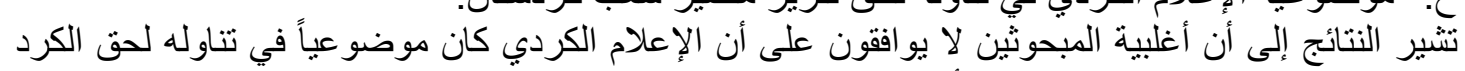

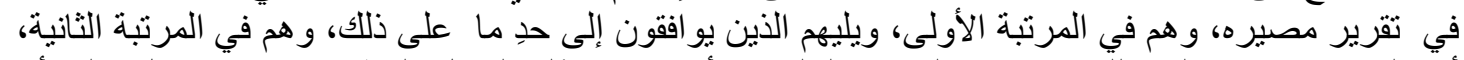

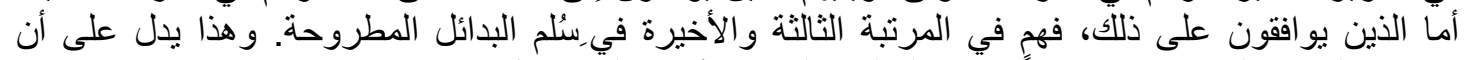

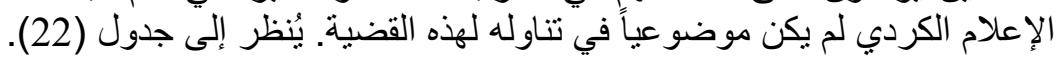

\begin{tabular}{|c|c|c|c|c|c|c|c|}
\hline \multicolumn{8}{|c|}{ جدول(22): موضو عية الإعلام الكردي في تناوله لحق تقرير مصبر شعب كردستان. } \\
\hline المرتبة & $\%$ & 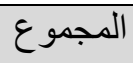 & $\%$ & إناث & $\%$ & ذكور & البدائل \\
\hline الثالثة & 4 & 2 & 2 & 1 & 2 & 1 & أو افق \\
\hline الثانية & 38 & 20 & 9 & 5 & 26 & 14 & إلى حذ ما \\
\hline 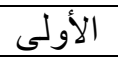 & 61 & 31 & 19 & 10 & 42 & 22 & لا أوافق \\
\hline & 100 & 53 & 30 & 16 & 70 & 37 & المجموع \\
\hline
\end{tabular}

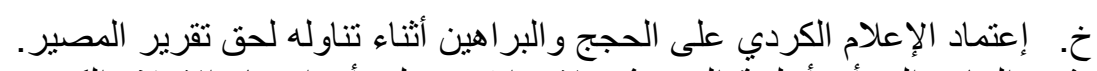

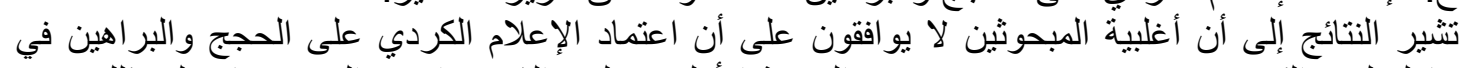

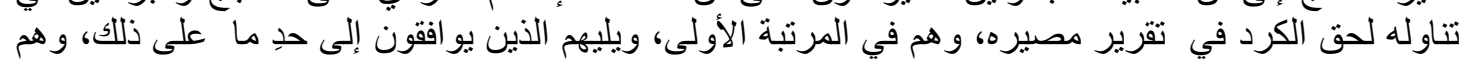




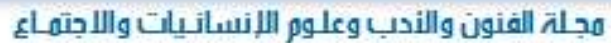 \\ عند خلم بالهونمر العلمي اللاول لقسر التقنية اللاعلامية \\ كلية التقنية اللدازية -جاهعت السليمانية التقنية \\ " \\ www.jalhss.com ISSN online: 2414-3383 ISSN print 2616-3810

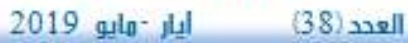

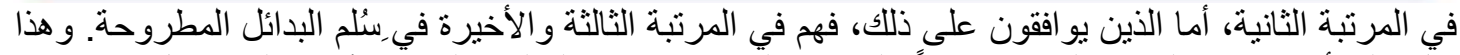

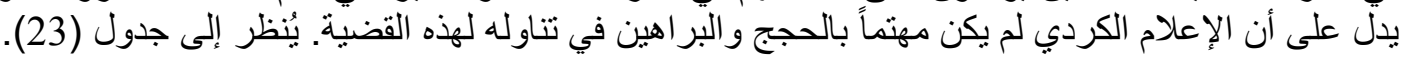

\begin{tabular}{|c|c|c|c|c|c|c|c|}
\hline \multicolumn{8}{|c|}{ جدول(23): إعتماد الإعلام الكردي على الحجج والبر اهين في تناوله لحق تقرير المصير. } \\
\hline 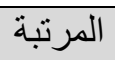 & $\%$ & 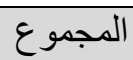 & $\%$ & إناث & $\%$ & ذكور & البدائل \\
\hline 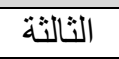 & 4 & 2 & 2 & 1 & 2 & 1 & أو افق \\
\hline الثانية & 39 & 21 & 11 & 6 & 28 & 15 & 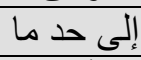 \\
\hline الأولى & 57 & 30 & 17 & 9 & 40 & 21 & لا أو افق \\
\hline & 100 & 53 & 30 & 16 & 70 & 37 & المجموع \\
\hline
\end{tabular}

د. مَركزة قضية حق تقرير المصير في معظم المضامين التي يعرضها الإعلام الكردي.

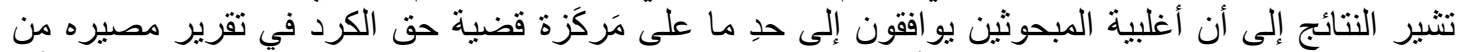

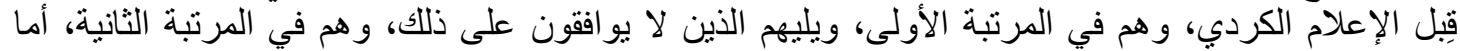

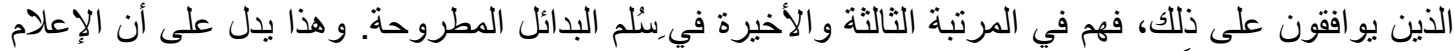
الكردي لم يكن مهتماً بمركزة هذه القضية في مضامينه الإعلامية. يُنظر إلى جدول النية (24).

\begin{tabular}{|c|c|c|c|c|c|c|c|}
\hline \multicolumn{8}{|c|}{ جدول(24): مَركزة قضية حق تقرير المصير في معظم المضامين التي يعرضها الإعلام الكردي، } \\
\hline المرتبة & $\%$ & 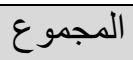 & $\%$ & إناث & $\%$ & ذكور & البدائل \\
\hline 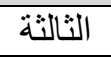 & 2 & 1 & 2 & 1 & 0 & 0 & أو افق \\
\hline الأولى & 51 & 27 & 21 & 11 & 30 & 16 & 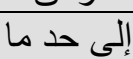 \\
\hline الثانية & 47 & 25 & 7 & 4 & 40 & 21 & لا أو افق \\
\hline & 100 & 53 & 30 & 16 & 70 & 37 & المجموع \\
\hline
\end{tabular}

3. الإعلام الكردي و أساليبه الإقناعية:

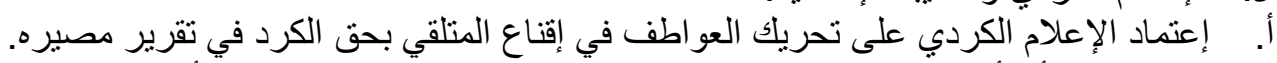

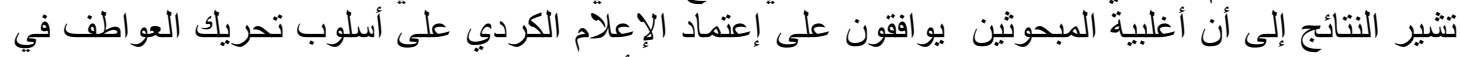

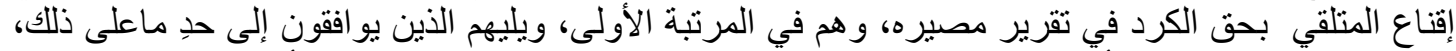

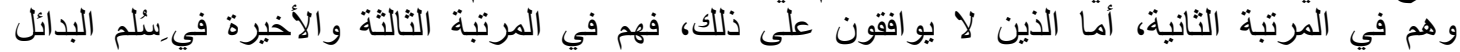

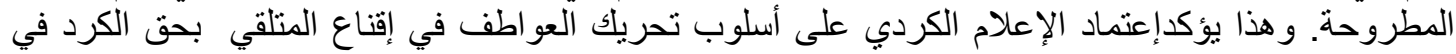

تقرير مصيره. يُنظر إلى جدول (25).

\begin{tabular}{|c|c|c|c|c|c|c|c|}
\hline \multicolumn{8}{|c|}{ جدول(25): إعتماد الإعلام الكردي على تحريك العواطف في إقناع المتلقي بشأن هذا الحق. } \\
\hline المرتبة & $\%$ & 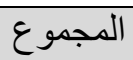 & $\%$ & إناث & $\%$ & ذكور & البدائل \\
\hline 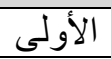 & 55 & 29 & 13 & 7 & 42 & 22 & 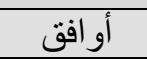 \\
\hline الثانية & 32 & 17 & 11 & 6 & 21 & 11 & 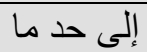 \\
\hline 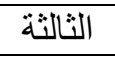 & 13 & 7 & 6 & 3 & 7 & 4 & 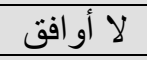 \\
\hline & 100 & 53 & 30 & 16 & 70 & 37 & المجموع \\
\hline
\end{tabular}




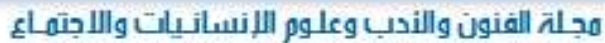 \\ عدد خام بالهونتمر العلهي اللاول لقسم التقنية اللـ عامية \\ كلية التقنية الليدارية-جامعت السليهانية التقنية}

"

www.jalhss.com ISSN online: 2414-3383 ISSN print 2616-3810

2019 العدي

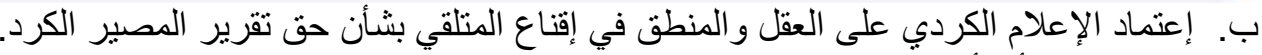

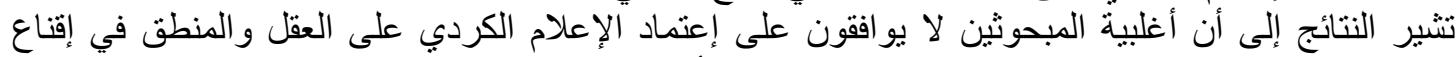

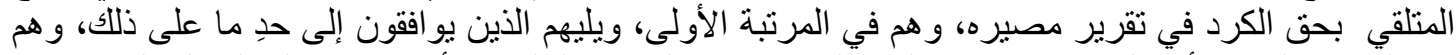

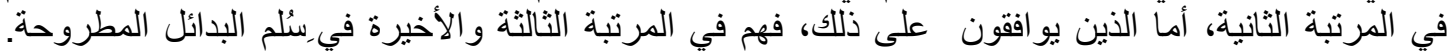
و هذا يؤكد عدم إعتماد الإعلام الكردي على العقل والمنطق في إقناع المتلقي بحق التق الكرد في تقرير مصبره.

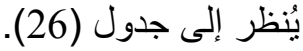

\begin{tabular}{|c|c|c|c|c|c|c|c|}
\hline \multicolumn{8}{|c|}{ جدول (26): إعنماد الإعلام الكردي على العقل و المنطق في إقناع المتلقي بشأن هذا الحق. } \\
\hline 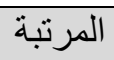 & $\%$ & 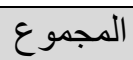 & $\%$ & إناث & $\%$ & ذكور & البدائل \\
\hline الثالثة & 4 & 2 & 0 & 0 & 4 & 2 & أو افق \\
\hline الثانية & 43 & 23 & 15 & 8 & 28 & 15 & إلى حد ما \\
\hline 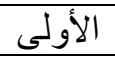 & 53 & 28 & 15 & 8 & 38 & 20 & لا أو افق \\
\hline & 100 & 53 & 30 & 16 & 70 & 37 & المجموع \\
\hline
\end{tabular}

ت. إعتماد الإعلام الكردي على أسلوب التخويف في إقناع المتلقي بشأن هذا الحق.

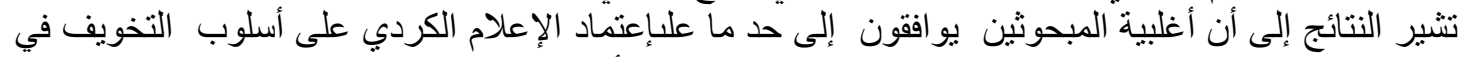

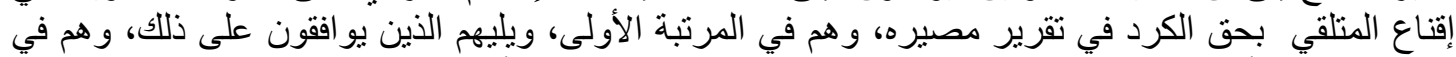

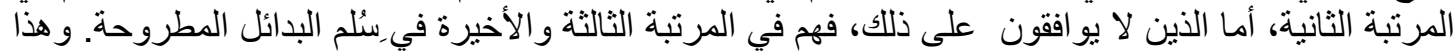

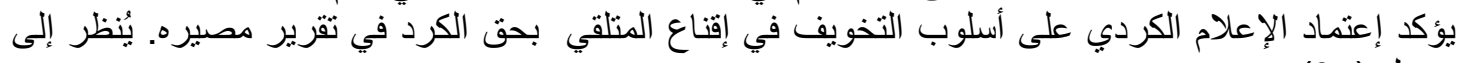
جدول (27).

\begin{tabular}{|c|c|c|c|c|c|c|c|}
\hline \multicolumn{8}{|c|}{ جدول (27): إعتماد الإعلام الكردي على أسلوب التخويف في إقناع المتلقي بشأن هذا الحق. } \\
\hline 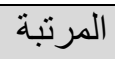 & $\%$ & 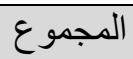 & $\%$ & إناث & $\%$ & ذكور & البدائل \\
\hline الثانية & 28 & 15 & 11 & 6 & 17 & 9 & أوافق \\
\hline 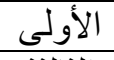 & 51 & 27 & 9 & 5 & 42 & 22 & 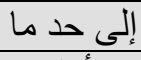 \\
\hline 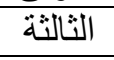 & 21 & 11 & 9 & 5 & 11 & 6 & لا أو افق \\
\hline & 100 & 53 & 30 & 16 & 70 & 37 & المجموع \\
\hline
\end{tabular}

ث. إعتماد الإعلام الكردي على التكرار المستمر في إقناع المتلقي بشأن حتى التقرير.

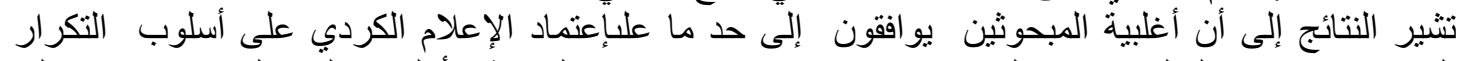

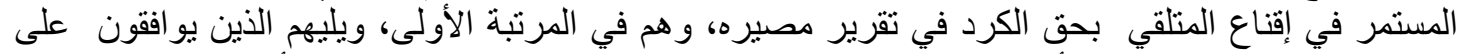

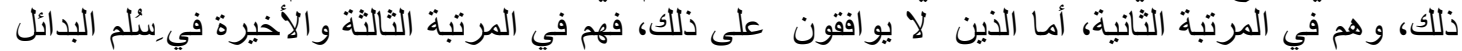

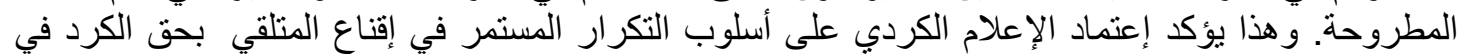

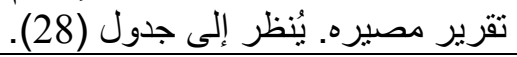

\begin{tabular}{|c|c|c|c|c|c|c|c|}
\hline \multicolumn{8}{|c|}{ جدول (28): إعتماد الإعلام الكردي على التكرار المستمر في إقناع المنلقي بشأن هذا الحق. } \\
\hline 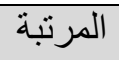 & $\%$ & 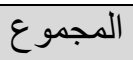 & $\%$ & 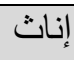 & $\%$ & ذكور & البدائل \\
\hline الثانية & 21 & 11 & 6 & 3 & 15 & 8 & أو افق \\
\hline 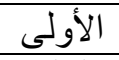 & 64 & 34 & 21 & 11 & 43 & 23 & 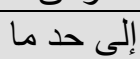 \\
\hline الثالثة & 15 & 8 & 4 & 2 & 11 & 6 & لا أو افق \\
\hline & 100 & 53 & 31 & 16 & 69 & 37 & المجموع \\
\hline
\end{tabular}




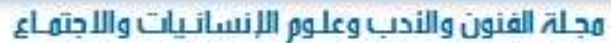 \\ عد خلم بالهوتمر العلمي اللاول القسر التقنية اللاعلامية \\ كلية التقنية اللدازية -جامعت السليمانية التقنية

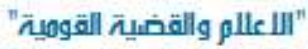 \\ www.jalhss.com ISSN online: 2414-3383 ISSN print 2616-3810

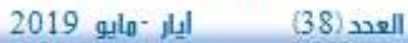

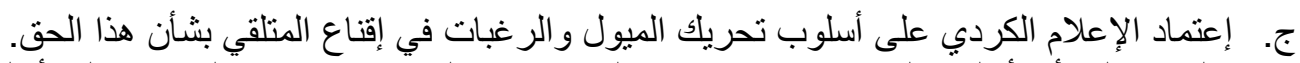

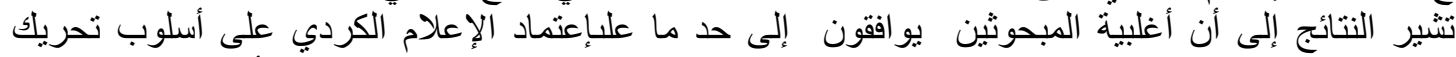

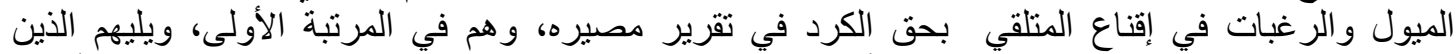

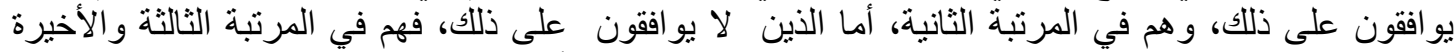

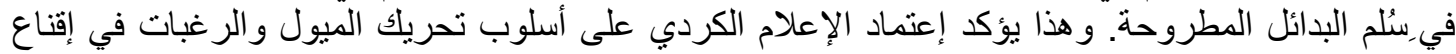

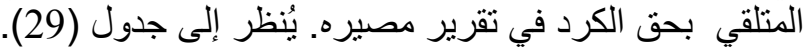

\begin{tabular}{|c|c|c|c|c|c|c|c|}
\hline \multicolumn{8}{|c|}{ جدول (29): إعتماد الإعلام الكردي على تحريك الميول و الرغبات في إقناع المتلقي بشأن هذا الحق. } \\
\hline 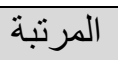 & $\%$ & 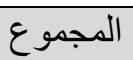 & $\%$ & إناث & $\%$ & ذكور & البدائل \\
\hline الثانبة & 32 & 17 & 11 & 6 & 21 & 11 & أو افق \\
\hline 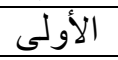 & 57 & 30 & 17 & 9 & 40 & 21 & إلى حد ما \\
\hline الثالثة & 11 & 6 & 2 & 1 & 9 & 5 & لا أو افق \\
\hline & 100 & 53 & 30 & 16 & 70 & 37 & المجموع \\
\hline
\end{tabular}

ح. إعتماد الإعلام الكردي على تثكيل الصور الذهنية في إقناع المتلقي بشأن هذا الحثق.

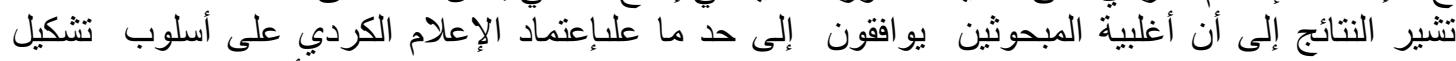

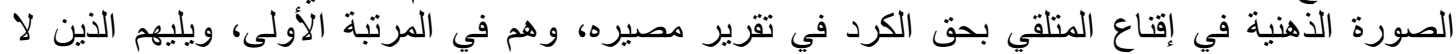

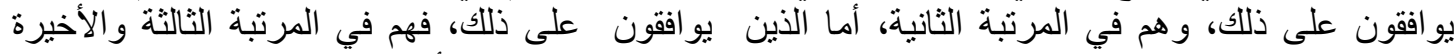

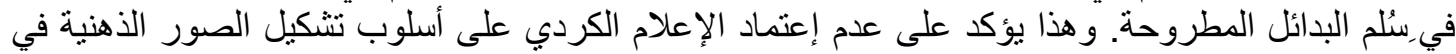

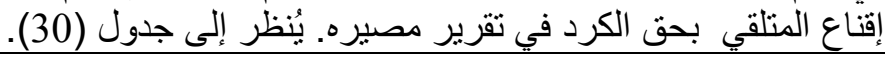

\begin{tabular}{|c|c|c|c|c|c|c|c|}
\hline \multicolumn{8}{|c|}{ جدول (30): إعتماد الإعلام الكردي على تشكيل الصور الذهنية في إقناع المتلقي بهذا الحق. } \\
\hline 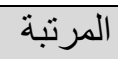 & $\%$ & 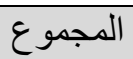 & $\%$ & إناث & $\%$ & ذكور & البدائل \\
\hline 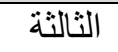 & 9 & 5 & 2 & 1 & 8 & 4 & 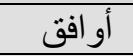 \\
\hline 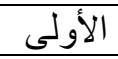 & 61 & 32 & 19 & 10 & 42 & 22 & 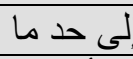 \\
\hline الثانية & 30 & 16 & 9 & 5 & 21 & 11 & لا لأو افق \\
\hline & 100 & 53 & 30 & 16 & 70 & 37 & المجموع \\
\hline
\end{tabular}

خ. عرض الإعلام الكردي لملخص النتائج التي يدركها في معالجاته الإعلامية، دائماً.

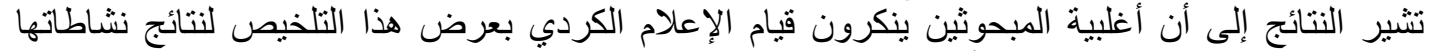

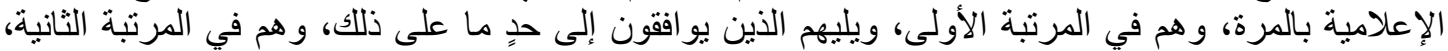

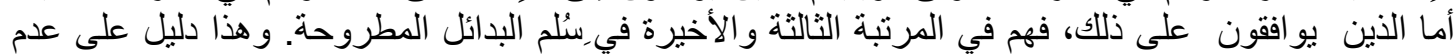

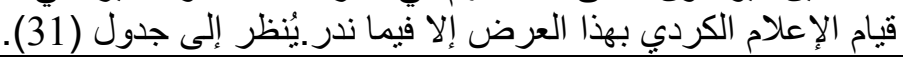

\begin{tabular}{|c|c|c|c|c|c|c|c|}
\hline \multicolumn{8}{|c|}{ جدول (31): إعتماد الإعلام الكردي على تحريك العو اطف في إقناع المتلقي بشأن هذا الحق. } \\
\hline 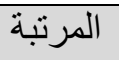 & $\%$ & 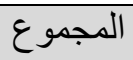 & $\%$ & إناث & $\%$ & ذكور & البدائل \\
\hline الثالثة & 2 & 1 & 2 & 1 & 0 & 0 & 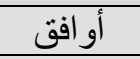 \\
\hline الثانية & 47 & 25 & 9 & 5 & 38 & 20 & 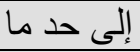 \\
\hline 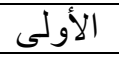 & 51 & 27 & 19 & 10 & 32 & 17 & لا أو افق \\
\hline & 100 & 53 & 30 & 16 & 70 & 37 & المجموع \\
\hline
\end{tabular}




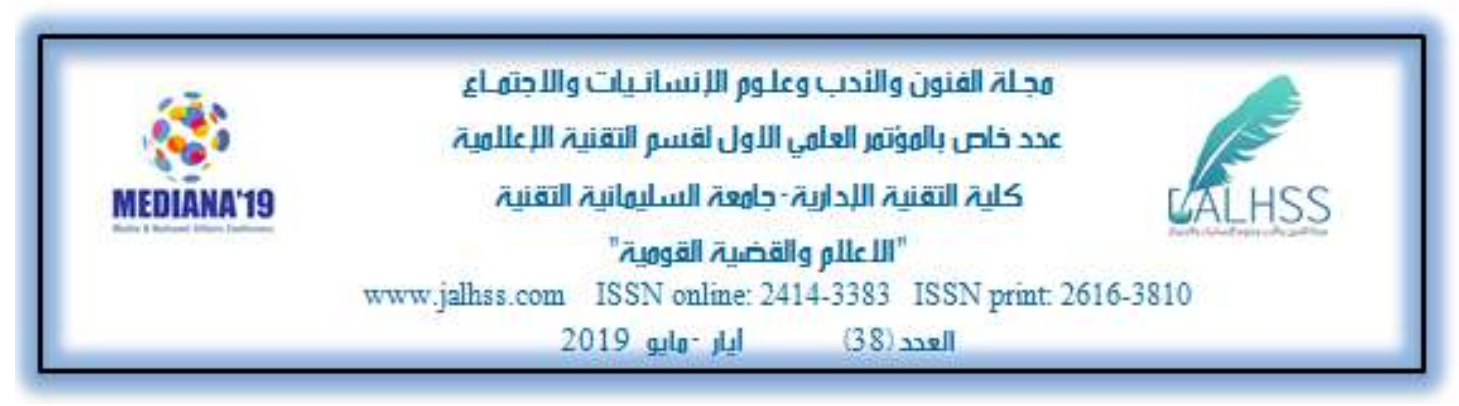

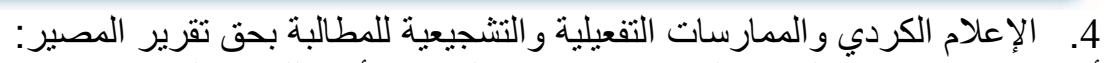

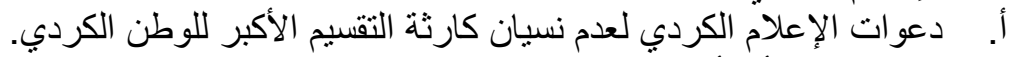

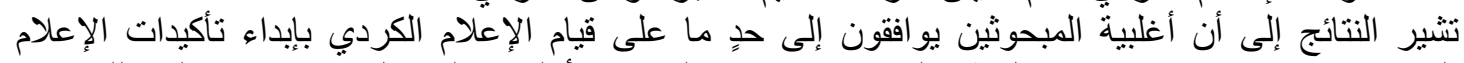

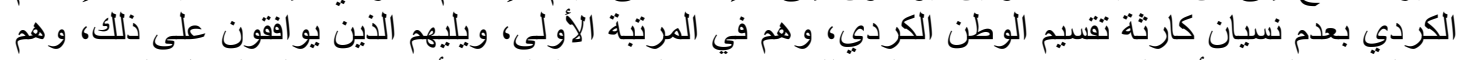

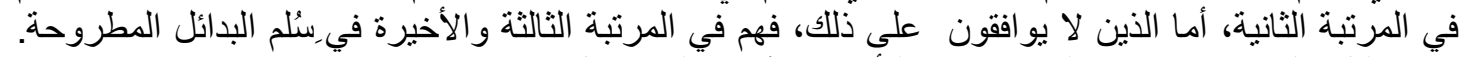

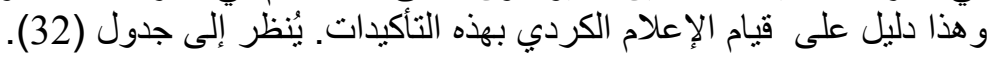

\begin{tabular}{|c|c|c|c|c|c|c|c|}
\hline \multicolumn{8}{|c|}{ جدول (32): تأكيدات الإعلام الكردي بعدم نسيان كارثة تقسيم الوطن الكردي. } \\
\hline 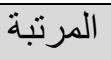 & $\%$ & 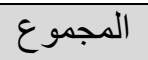 & $\%$ & إناث & $\%$ & ذكور & البدائل \\
\hline الثانية & 30 & 16 & 11 & 6 & 19 & 10 & أو افق \\
\hline 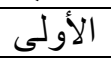 & 59 & 31 & 17 & 9 & 42 & 22 & 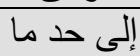 \\
\hline الثالثة & 11 & 6 & 2 & 1 & 9 & 5 & لا ل أو افق \\
\hline & 100 & 53 & 30 & 16 & 70 & 37 & 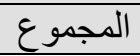 \\
\hline
\end{tabular}

ب. الإعلام الكردي و مقارنة واقع الكرد ووطنه بواقع غبره من الأمم و الأوطان.

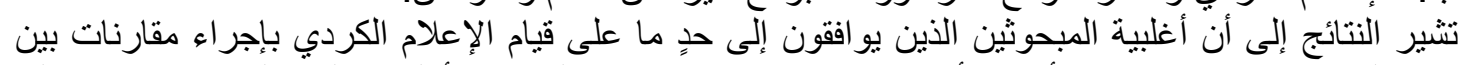

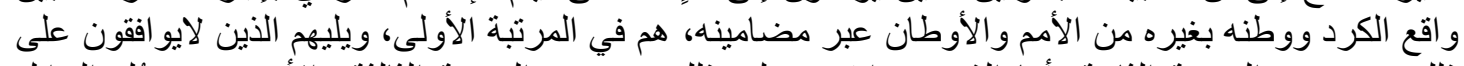

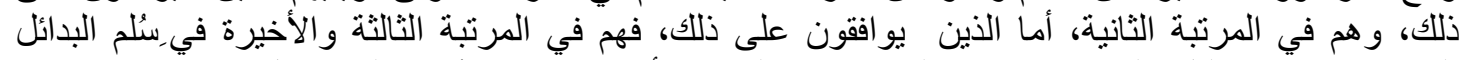

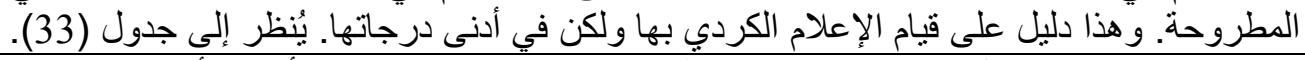

\begin{tabular}{|c|c|c|c|c|c|c|c|}
\hline \multicolumn{8}{|c|}{ جدول (33): مقارنة و اقع الكرد ووطنه بو اقع غيره من الأمم والأوطان. } \\
\hline 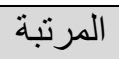 & $\%$ & المجموع & $\%$ & 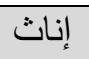 & $\%$ & ذكور & البدائل \\
\hline 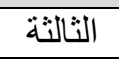 & 13 & 7 & 4 & 2 & 9 & 5 & أو افق \\
\hline الأولى & 70 & 37 & 23 & 12 & 47 & 25 & 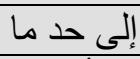 \\
\hline الثانية & 17 & 9 & 4 & 2 & 13 & 7 & لا أو افق \\
\hline & 100 & 53 & 31 & 16 & 69 & 37 & المجموع \\
\hline
\end{tabular}

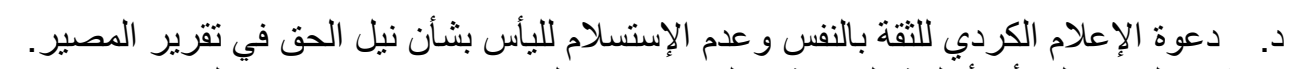

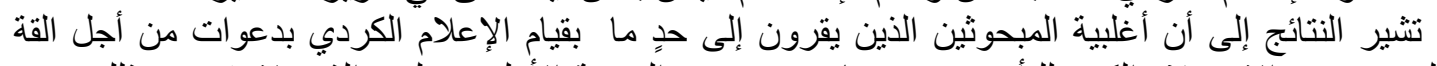

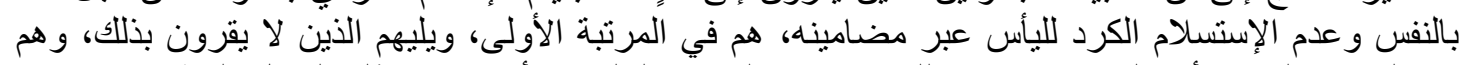

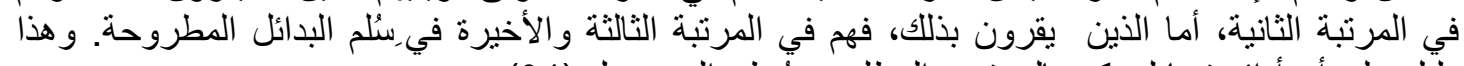

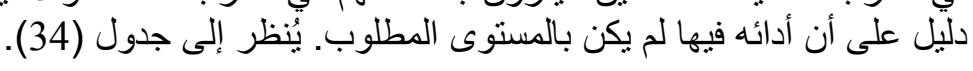

\begin{tabular}{|c|c|c|c|c|c|c|c|}
\hline \multicolumn{8}{|c|}{ جدول (34): دعوة الإعلام الكردي للثقة بالنفس و عدم الإستسلام بشأن هذا الحق. } \\
\hline 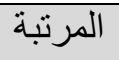 & $\%$ & 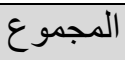 & $\%$ & إناث & $\%$ & ذكور & البدائل \\
\hline الثالثة & 4 & 2 & 0 & 0 & 4 & 2 & أو افق \\
\hline 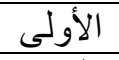 & 59 & 31 & 19 & 10 & 40 & 21 & 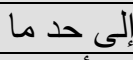 \\
\hline الثانية & 37 & 20 & 11 & 6 & 26 & 14 & لا أو افق \\
\hline & 100 & 53 & 30 & 16 & 70 & 37 & المجموع \\
\hline
\end{tabular}




\section{कृष \\ MEDIANA'19 \\ مجِ لات الفنون والندب وعاوم اللإنسانيات واللاجتهاع \\ عدد خام بالهوتمر العلهي اللاول لقسم التقنية اللاعلامية \\ كلية التقنية الليدارية-جامعت السليهانية التقنية}

"

www.jalhss.com ISSN online: $2414-3383$ ISSN print $2616-3810$

2019 العدي

ت. ت الإعلام الكردي و التذكير الكرد بالكو ارث المؤلمة كحملات الأنفال و الحلبجة و و الثنكال.

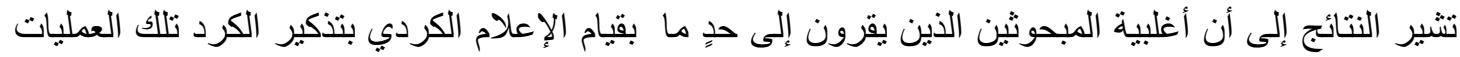

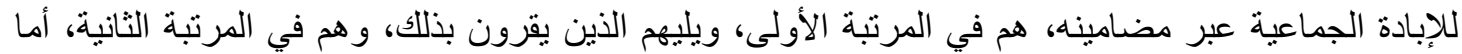

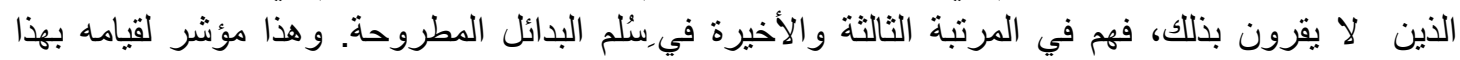

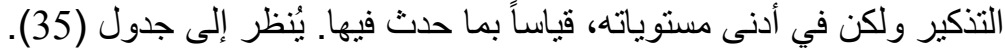
جدول (35): قيام الإعلام الكردي بتذكير الكرد بعمليات الإبادة الجماعية.

\begin{tabular}{|c|c|c|c|c|c|c|c|}
\hline \multicolumn{8}{|c|}{ جدول (35): قيام الإعلام الكردي بتذكير الكرد بعمليات الإبادة الجماعية. } \\
\hline 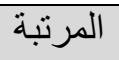 & $\%$ & 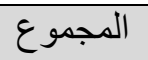 & $\%$ & إناث & $\%$ & ذكور & البدائل \\
\hline الثانية & 23 & 12 & 8 & 4 & 15 & 8 & أو افق \\
\hline الأولى & 58 & 31 & 23 & 12 & 36 & 19 & 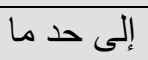 \\
\hline 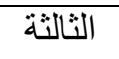 & 19 & 10 & 0 & 0 & 19 & 10 & 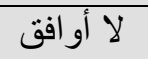 \\
\hline & 100 & 53 & 30 & 16 & 70 & 37 & 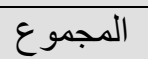 \\
\hline
\end{tabular}

ح. دعوة الإعلام الكردي ليكون الإعلام وطنياً ومدافعاً عنيداً عن حق الكرد في تقرير مصبير ها.

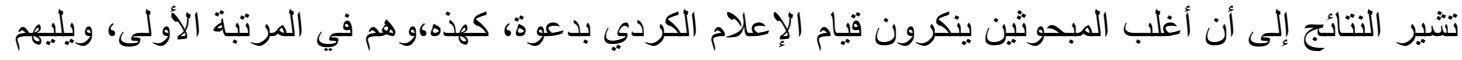

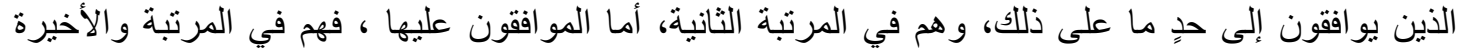

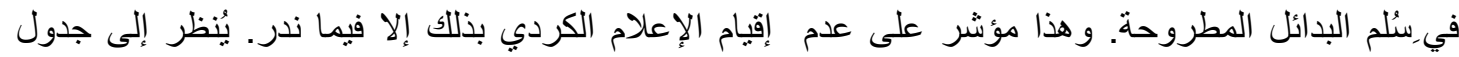

\begin{tabular}{|c|c|c|c|c|c|c|c|}
\hline \multicolumn{8}{|c|}{ جدول(36): الإعلام الكردي يدعو إلى إقامة إعلاما وطنيا قادرا على الدفاع عن الكرد في تقرير مصبره. } \\
\hline المرتبة & $\%$ & 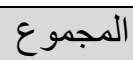 & $\%$ & إناث & $\%$ & ذكور & البدائل \\
\hline الثالثة & 4 & 2 & 2 & 1 & 2 & 1 & أو افق \\
\hline الثانية & 30 & 16 & 9 & 5 & 21 & 11 & 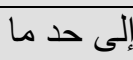 \\
\hline 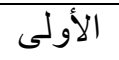 & 66 & 35 & 19 & 10 & 47 & 25 & لا أو افق \\
\hline & 100 & 53 & 30 & 16 & 70 & 37 & 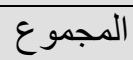 \\
\hline
\end{tabular}

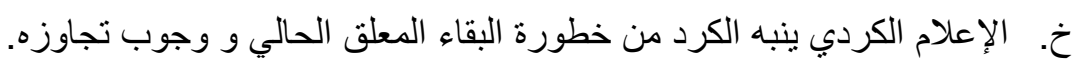

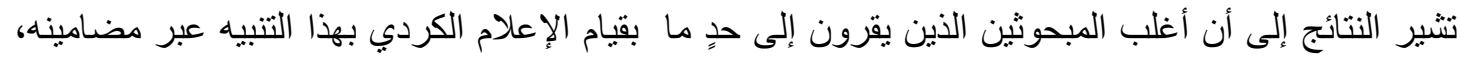

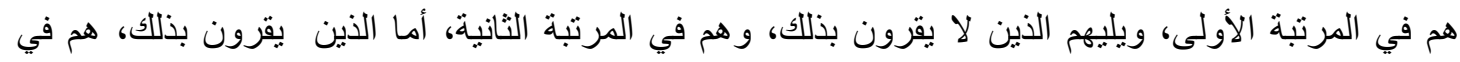
المرتبة الثالثة والأخيرة في سُّلم البدائل المطروحة. وهذا مؤشر لعدم قيامه بمثل هذا التذكير. يُنظر إلى جدول

\begin{tabular}{|c|c|c|c|c|c|c|c|}
\hline \multicolumn{8}{|c|}{ جدول (37): الإعلام الكردي ينبه الكرد من خطورة البقاء المعلق الحالي ووجوب تجاوزه } \\
\hline المرتبة & $\%$ & 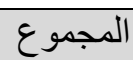 & $\%$ & 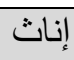 & $\%$ & ذكور & البدائل \\
\hline الثالثة & 15 & 8 & 6 & 3 & 9 & 5 & 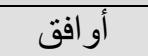 \\
\hline الأولى & 57 & 30 & 13 & 7 & 44 & 23 & 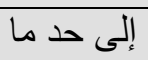 \\
\hline الثانية & 28 & 15 & 11 & 6 & 17 & 9 & لا أو افق \\
\hline & 100 & 53 & 30 & 16 & 70 & 37 & 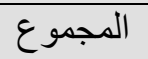 \\
\hline
\end{tabular}




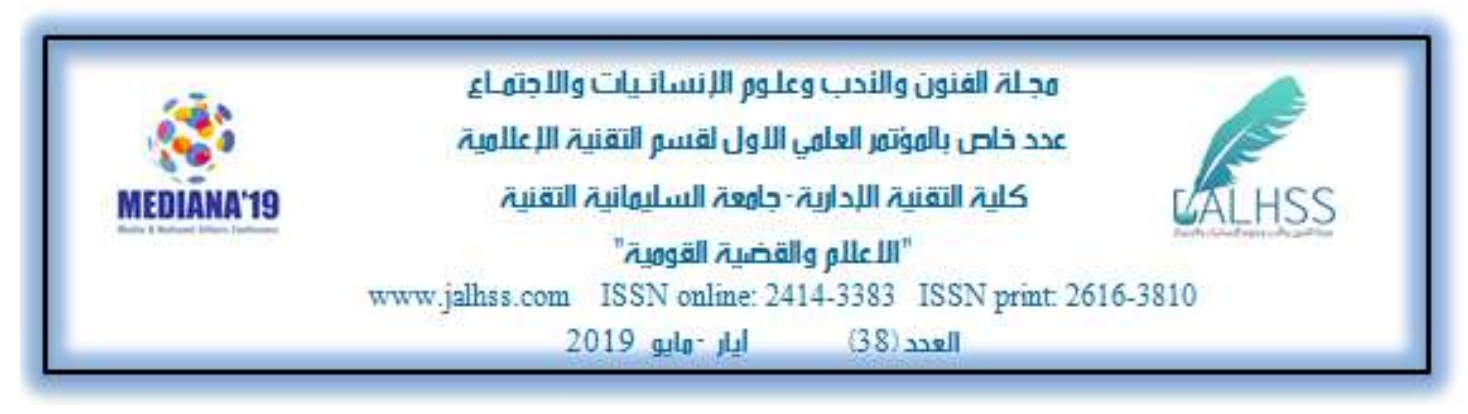

د. دعوات الإعلام الكردي للإفاع عن حقوق الأفراد و إنشاء نظام ديمقر اطي في إقليم كردستان.

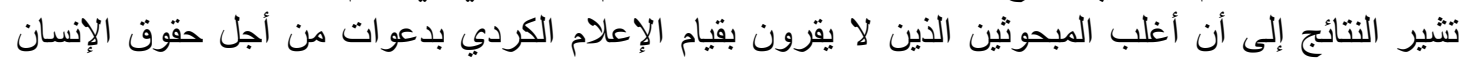

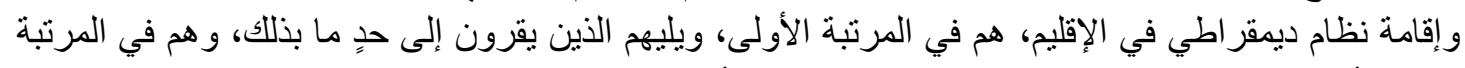

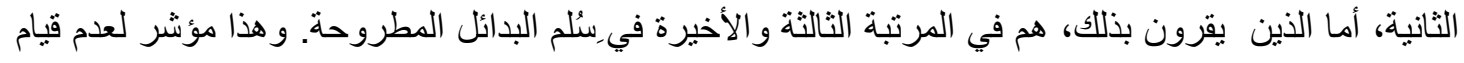

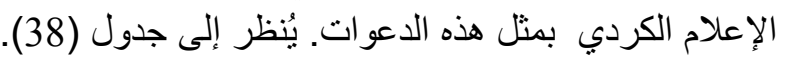

\begin{tabular}{|c|c|c|c|c|c|c|c|}
\hline \multicolumn{8}{|c|}{ جدول (38): دعوات الإعلام الكردي للدفاع عن حقوق الفرد الكردي و إنشاء نظام ديمقر اطي في الإقليم. } \\
\hline المرتبة & $\%$ & 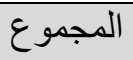 & $\%$ & 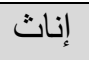 & $\%$ & ذكور & البدائل \\
\hline الثالثة & 4 & 2 & 0 & 0 & 4 & 2 & أو افق \\
\hline الثانية & 39 & 21 & 9 & 5 & 30 & 16 & 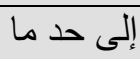 \\
\hline 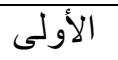 & 57 & 30 & 21 & 11 & 36 & 19 & 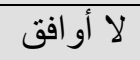 \\
\hline & 100 & 53 & 30 & 16 & 70 & 37 & 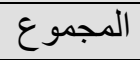 \\
\hline
\end{tabular}

\section{الإستتناجات والتوصيات والمقترحات}

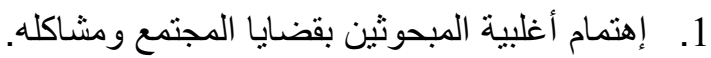

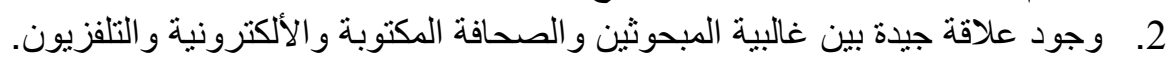

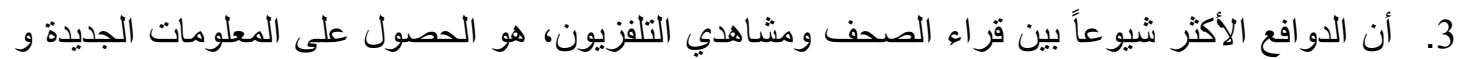
التعرف على ثقافات وتجارب الآخرين في الحياة.

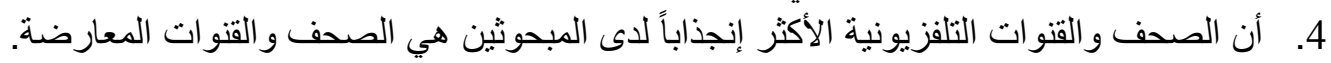

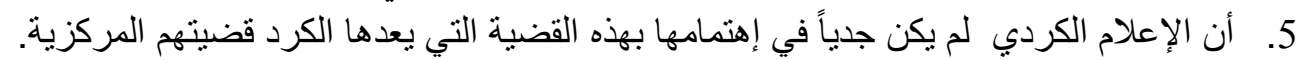

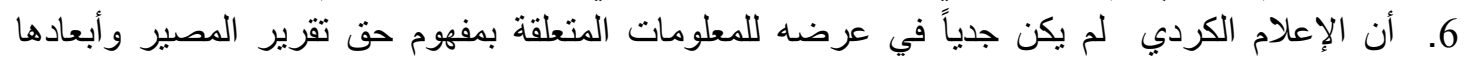
البنيوية، بشكل تلليق بمكانتها و أهميتها لدى الإعل الكرد.

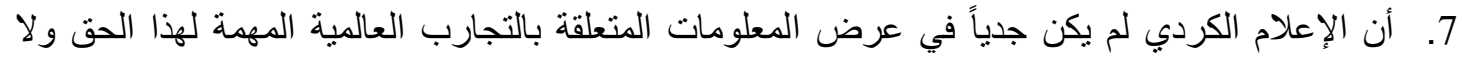
بمحاو لات الشعوب من أجله. 8. أن الإعلام الكردي لم يكن جاداً في تناول هذا الحق الكردي المشروع، .تناو لاً إستقصائياً ومعرفياً بهدف إز الة الغموض و الملابسات عنها.

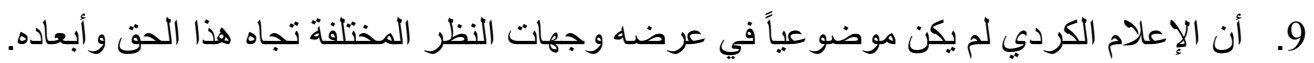

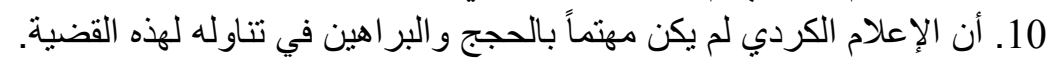

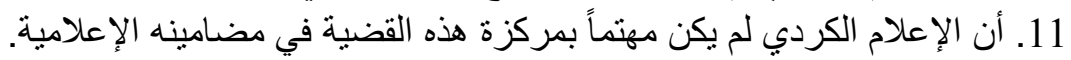

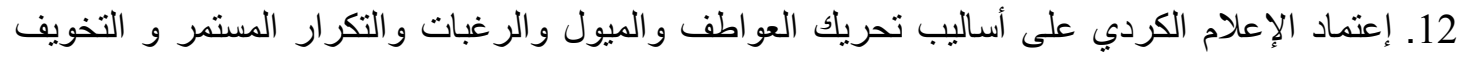

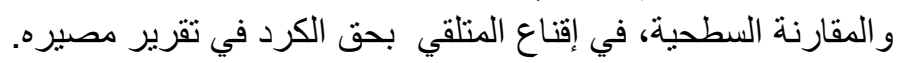

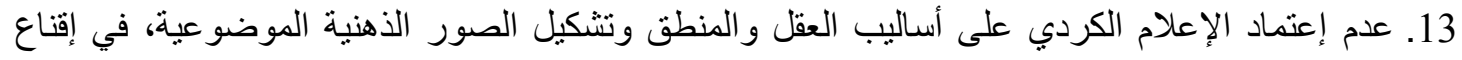
المتلقي بحق الكرد في تقرير مصبره. 14. عدم قيام الإعلام الكردي بعرض فير التلخيص لنتيص لنتائج نشاطاتها الإعلامية بالمرة . 


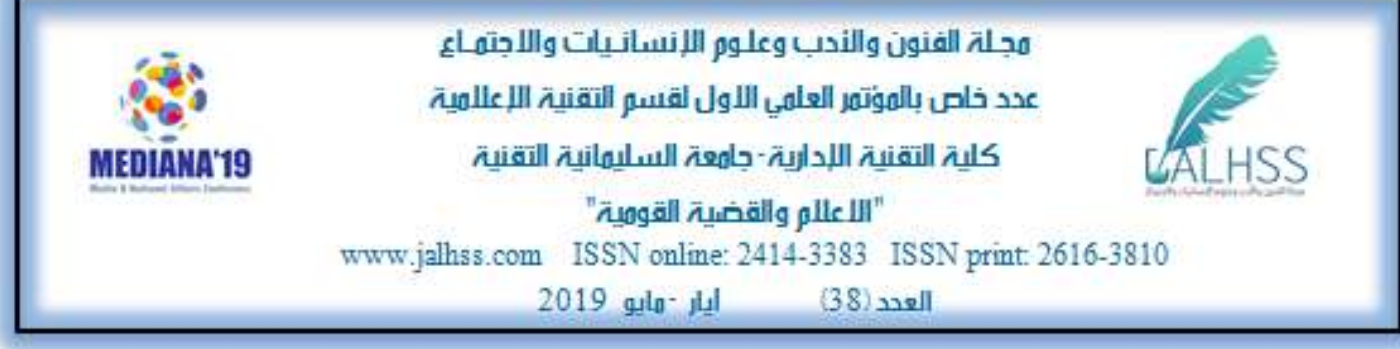

15. قيام الإعلام الكردي بإبداء تأكيدات على عدم نسيان كارثة التقسيم الدولي للوطن الكردي.

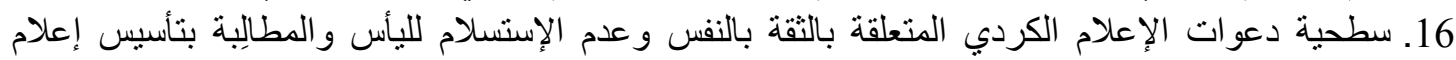
وطني في الأقليم والدفاع عن حقوق الأفر اد و إنشاء نظام ديمقر اطي فيها.

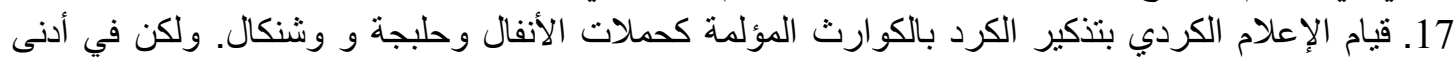
مستو ياته، قياساً بما حدث فيها.

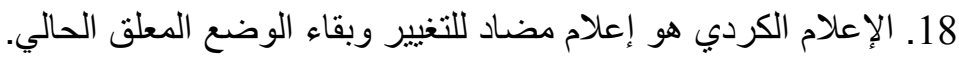

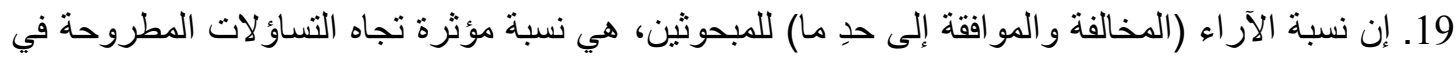

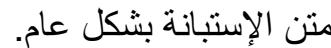

التوصيات

1. ان يطرح الاعلام الكردي الموضوعات المتعلقة بحق تقرير المصير بشكل اكثر عقلانية.

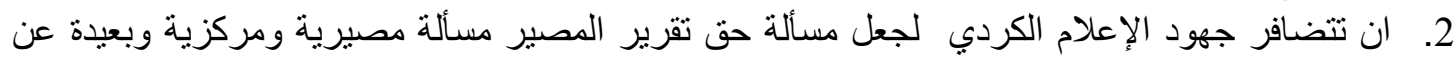
و المصالح و الاهو اء السياسية.

\section{المقترحات}

1. تنظيم حملات اعلامية منظمة تشترك به وسائل الاعلام الكردية كافة، بهدف تعبئة الجماهير الكردية بشكل دوري ودائم حول قضية تقرير المصير.

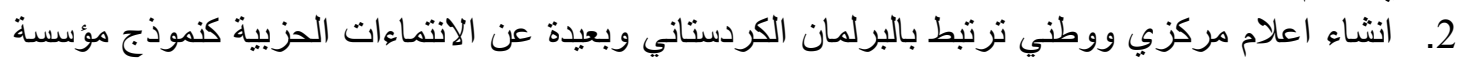
البريطانية.

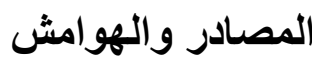

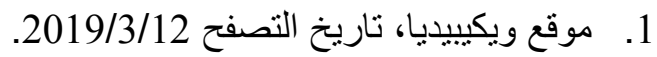

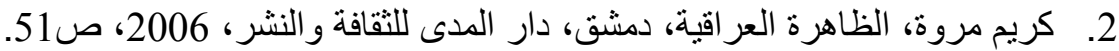
3. سعد بشير اسكندر، الديمقراطية وحق تقرير المصبر، السليمانية، منشورات مكتب الفكر و التوعية في

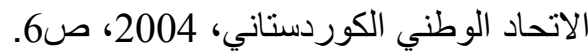
4. . وائل احمد علام، حماية حقوق الاقليات في القانون الدولي العام، مكان الطبع غير مذكور، دار النهضة العربية، ط2 5. عيسى دباح، موسوعة القانون الدولي (المجلد الخامس)، عمان، دار الثروق للنشر و التوزيع، 2003، ص158. 6. جليل جليلي وآخرون، الحركة الكردية في العصر الحديث، ط2، ت:عبدي حاجي، بيروت، دار الفار ابي، (2013، ص: 2013. 7.

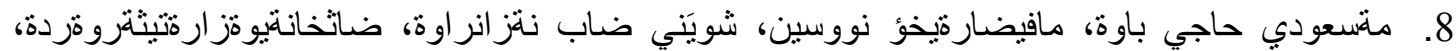
111 1998 


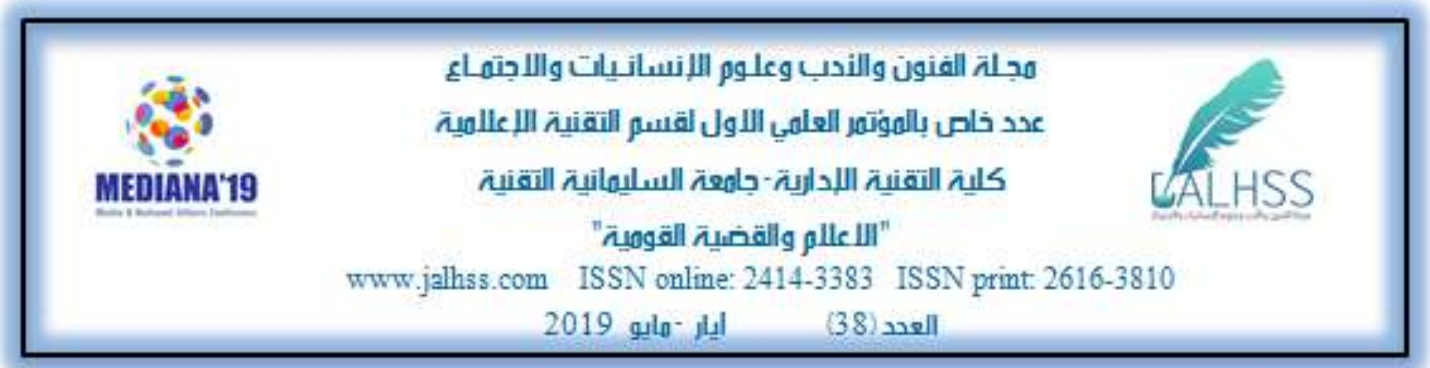

9. حنا بطاطو، العراق (الكتاب الا ول)، ت: عفيف الرزاز،بيروت، مؤسسة الابحاث العربية، 1990، ص ص95. n

10. سعد بشير اسكندر، كردستان العراق الجذور التاريخية لمشروع الفيدرالية، بغداد، معهد الدراسات

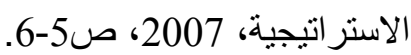

11.شورش حسن عمر، حقوق الثعب الكردي في الدساتير العراقية، السليمانية، مركز كردستان للاراسات

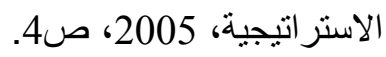

